\title{
TOWARD SUSTAINABLE HUMAN DEVELOPMENT IN VENEZUELA: DIAGNOSIS, CHALLENGES AND ECONOMIC STRATEGY
}

\author{
Francisco Rodríguez 1 \\ Guillermo Guerrero²
}

\begin{abstract}
The Venezuelan crisis has become one of the most dramatic of Latin American history. Venezuela has had the worst economic contraction of the region, has been focus to a sharp increase in extreme poverty levels, and has become the country with the largest refugee crisis of the continent. As the situation deteriorated, data sources have also reduced drastically by the government, which renders it difficult to assess the complete depth of the country's economic crisis and adds another layer of complexity. Despite the Venezuelan collapse being staggering, few academics studies have attempted to identify its causes. This article addresses this gap and aims to understand the drivers of Venezuelan economic downfall. We provide a comprehensive diagnosis of the Venezuelan collapse and suggest the means to put Venezuela back on the road of sustainable development.
\end{abstract}

Keywords: Venezuela; economic crisis; human sustainable development.

\section{RUMO AO DESENVOLVIMENTO HUMANO SUSTENTÁVEL NA VENEZUELA: DIAGNÓSTICO, DESAFIOS E ESTRATÉGIA}

\begin{abstract}
A crise na Venezuela tornou-se uma das mais dramáticas da história da América Latina. A Venezuela apresentou os piores índices de contração econômica da região, foi foco de um aumento substantivo dos índices de pobreza extrema, e tornou-se o país com a pior crise de refugiados do continente. Ao passo que a situação deteriorou, as fontes de dados governamentais tornaram-se mais escassas, 0 que adiciona mais um nível de complexidade para a crise e dificulta sua análise detalhada. A despeito da profundidade da crise venezuelana, poucos estudos acadêmicos focaram analisar suas causas. Este artigo visa contribuir com o entendimento da crise apresentando uma análise das causas da crise econômica venezuelana. 0 trabalho apresenta um diagnóstico amplo do colapso venezuelano e recomendações para a retomada do desenvolvimento econômico e humano sustentável.
\end{abstract}

Palavras-chave: Venezuela; crise econômica; desenvolvimento humano sustentável.

\section{RUMBO AL DESARROLLO HUMANO SUSTENTABLE EN VENEZUELA: DIAGNÓSTICOS, DESAFÍOS Y ESTRATEGIA}

La crisis en Venezuela se ha convertido en una de las más dramáticas en la historia de América Latina. Venezuela mostró los peores índices de contracción económica de la región, fue objeto de un aumento sustancial de los índices de pobreza extrema y se convirtió en el país con la peor crisis de refugiados del continente. A medida que la situación se fue deteriorando, las fuentes de datos gubernamentales se hicieron más escasas, lo que añade otro nivel de complejidad a la crisis y dificulta su análisis detallado. A pesar de la profundidad de la crisis venezolana, pocos estudios académicos se han centrado en el análisis

1. Visiting fellow at the Kellogg Institute for International Studies at the University of Notre Dame. Orcid: <https:// orcid.org/0000-0002-3774-7517>.

2. Senior strategist at EMFI Securities. None of the views expressed here reflect the views of United Nations Development Programme (UNDP) nor of the authors' employers. Orcid: <https://orcid.org/0000-0001-7542-1537>. 
de sus causas. Este artículo pretende contribuir al entendimiento de la crisis presentando un análisis de las causas de la crisis económica venezolana. El documento presenta un amplio diagnóstico del colapso de Venezuela y hace recomendaciones para la reanudación del desarrollo económico y humano sostenible.

Palabras clave: Venezuela; crisis económica; desarrollo humano sustentable.

JEL: HOO.

DOI: http://dx.doi.org/10.38116/rtm23art11

Data de envio do artigo: 1/9/2020; Data de aceite: 12/9/2020.

\section{INTRODUCTION}

Venezuela is undergoing one of the deepest economic crises experienced by any nation in modern history. Since 2013, gross domestic product (GDP) has contracted by $61.7 \%$ and is expected by the International Monetary Fund (IMF) to fall an additional $15.0 \%$ this year, taking the total aggregate economic contraction between 2013 and 2020 to $68.1 \%$. Hyperinflation has so far reached 49.9 million percent from December 2017 to May 2020 (latest available Central Bank print), while poverty rates have tripled. A mass exodus has occurred, during which at least 5.2 million persons, or approximately one-sixth of the country's population, are estimated to have left the country.

Measured in terms of real per capita income, living standards peaked in 2012 and have fallen by $58.3 \%$ between that year and $2019 .{ }^{3}$ This figure is already the worse economic contraction registered in Latin America and the Caribbean since 1950, followed by a 58.2\% decline suffered by Nicaragua between 1977 and 1993. ${ }^{4}$ Significantly, this decline happens during peacetime, a factor that sets Venezuela apart from historical cases of otherwise comparable magnitude.

As a consequence of the decline in economic activity, poverty rates by income have risen considerably. The National Institute of Statistics (Instituto Nacional de Estatística - INE) registered income poverty rising from 24\% in 2012 to $33 \%$ in $1 \mathrm{H} 15$, its latest available print. These figures are, nonetheless, significantly lower than those presented in the Encuesta Nacional de Condiciones de Vida (Encovi) (National Living Conditions Survey) which is prepared by an association of leading local universities. ${ }^{5}$ Encovi results, which are available starting in 2014, show the poverty rate rising from $48 \%$ in 2014 to $94 \%$ in 2018 and $96 \%$ in 2019. Extrapolating the INE series by using the Encovi variation rates, we would conclude that poverty as calculated by INE has risen to $63.5 \%$ by 2019 , almost three times that of 2012 .

\footnotetext{
3. Because of the migration exodus, Venezuela is an atypical case in which the drop in GDP per capita is slightly lower than the drop in GDP.

4. We measure the accumulated decline in per capita GDP from each local maximum - provided that there is no higher local maximum before it - to each successive local minimum, and rank the largest declines in the results. We employ Penn World Tables (PWT) version 9.1 data for all countries, except Cuba (World Bank) and Venezuela (official central bank data and IMF estimates). Data is not uniformly available from 1950 for all countries, as some series start at later years.

5. Available at: <https://www.proyectoencovi.com/>.
} 
TABLE 1

Largest output contractions, world (1950-2018/2019)

\begin{tabular}{|c|c|c|c|c|c|c|}
\hline Rank & Country & $\begin{array}{l}\text { Trough-to-peak ratio } \\
\text { (percentage decline) (\%) }\end{array}$ & Period & Years & $\begin{array}{l}\text { Average percentage } \\
\text { decline (\%) }\end{array}$ & $\begin{array}{l}\text { Years of initial } \\
\text { GDP lost (\%) }\end{array}$ \\
\hline 1 & Liberia & $-89,2$ & 1974-1995 & 21 & $-10,1$ & $-737,6$ \\
\hline 2 & Kuwait & $-86,8$ & 1970-1991 & 21 & $-9,2$ & $-1.134,0$ \\
\hline 3 & Iraq & $-77,3$ & 1979-1991 & 12 & $-11,6$ & $-366,8$ \\
\hline 4 & D.R. of the Congo & $-75,6$ & $1974-2002$ & 28 & $-4,9$ & $-1.191,0$ \\
\hline 5 & United Arab Emirates & $-72,4$ & $1970-2010$ & 40 & $-3,2$ & $-1.741,6$ \\
\hline 6 & Tajikistan & $-71,4$ & 1990-1996 & 6 & $-18,8$ & $-289,9$ \\
\hline 7 & Lebanon & $-70,8$ & 1974-1976 & 2 & $-45,9$ & $-102,1$ \\
\hline 8 & Georgia & $-70,7$ & 1990-1994 & 4 & $-26,4$ & $-214,8$ \\
\hline 9 & Islamic Republic of Iran & $-66,6$ & 1969-1988 & 19 & $-5,6$ & $-793,6$ \\
\hline 10 & Djibouti & $-66,5$ & $1971-2001$ & 30 & $-3,6$ & $-1.477,0$ \\
\hline 11 & Republic of Moldova & $-64,8$ & 1990-1999 & 9 & $-11,0$ & $-474,5$ \\
\hline 12 & Venezuela & $-64,2$ & $2012-2020$ & 8 & $-12,1$ & $-257,9$ \\
\hline 13 & Yemen & $-62,5$ & $2010-2017$ & 7 & $-13,1$ & $-252,4$ \\
\hline 14 & Azerbaijan & $-61,0$ & 1990-1995 & 5 & $-17,2$ & $-187,5$ \\
\hline 15 & Saudi Arabia & $-60,1$ & 1974-1987 & 13 & $-6,8$ & $-362,1$ \\
\hline 16 & Lebanon & $-58,8$ & 1987-1989 & 2 & $-35,8$ & $-86,9$ \\
\hline 17 & Gabon & $-58,6$ & $1976-2009$ & 33 & $-2,6$ & $-1.452,0$ \\
\hline 18 & Nicaragua & $-58,2$ & 1977-1993 & 16 & $-5,3$ & $-681,9$ \\
\hline 19 & Ukraine & $-57,7$ & 1990-1998 & 8 & $-10,2$ & $-324,0$ \\
\hline 20 & Sierra Leone & $-57,7$ & 1970-1999 & 29 & $-2,9$ & $-338,0$ \\
\hline
\end{tabular}

Source: PWT; IMF; World Bank.

TABLE 2

Largest GDP contractions, Latin America (1950-2018/2019)

\begin{tabular}{clccccc}
\hline Rank & Country & $\begin{array}{c}\text { Trough-to-peak ratio } \\
\text { (percentage decline) }\end{array}$ & Period & Years & $\begin{array}{c}\text { Average } \\
\text { percentage decline }\end{array}$ & $\begin{array}{c}\text { Years of initial } \\
\text { GDP lost (\%) }\end{array}$ \\
\hline 1 & Venezuela & $-64,2$ & $2012-2020$ & 8 & $-12,1$ & $-257,9$ \\
2 & Venezuela & $-58,3$ & $2012-2019$ & 7 & $-11,8$ & $-192,0$ \\
\hline 3 & Nicaragua & $-58,2$ & $1977-1993$ & 16 & $-5,3$ & $-681,9$ \\
4 & Haiti & $-45,3$ & $1980-2010$ & 30 & $-2,0$ & $-928,7$ \\
5 & Cuba & $-37,8$ & $1985-1993$ & 8 & $-5,8$ & $-94,8$ \\
6 & Peru & $-32,7$ & $1975-1992$ & 17 & $-2,3$ & $-221,0$ \\
7 & El Salvador & $-27,8$ & $1978-1983$ & 5 & $-6,3$ & $-94,1$ \\
8 & Bolivia & $-26,3$ & $1977-1986$ & 9 & $-3,3$ & $-115,7$ \\
9 & Chile & $-23,4$ & $1971-1975$ & 4 & $-6,4$ & $-46,9$ \\
10 & Argentina & $-23,2$ & $1979-1990$ & 11 & $-2,4$ & $-133,2$ \\
\hline
\end{tabular}

Source: PWT; IMF; World Bank. 
Tables 1 and 2 show a number of other measures of the magnitude of the economic contraction, together with the cross-national comparison. Venezuela's growth contraction has been very intense, taking place over just seven years. In contrast, Nicaragua’s GDP fell by $58.2 \%$ over a period lasting 16 years.

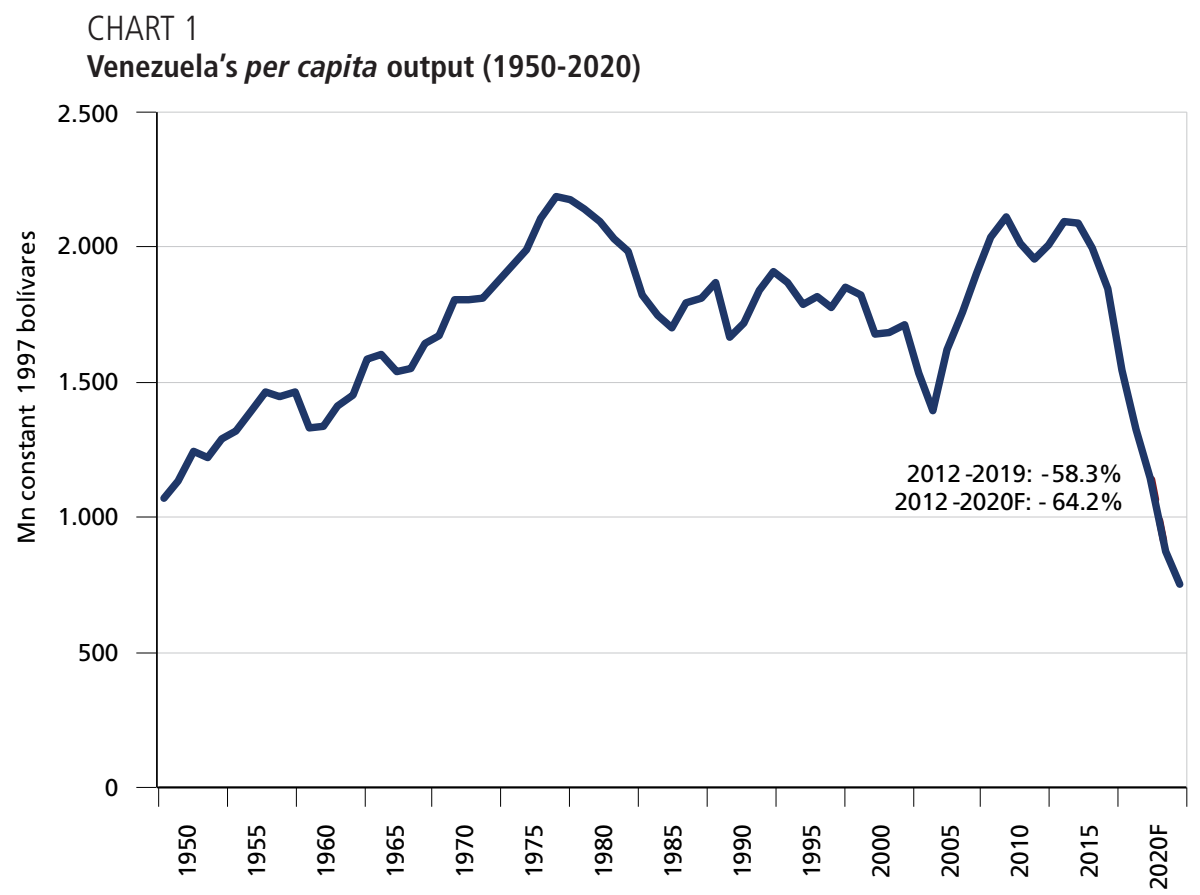

Source: Central Bank of Venezuela (BCV); IMF.

The same analytical issue can be found when looking at extreme poverty by income levels. INE shows the later statistic rising from 7\% in 2012 to $9 \%$ in $1 \mathrm{H} 15$, but Encovi results show a significantly higher 20.6\% for 2014 rising to $79.3 \%$ in 2017, its latest available print. The Encovi survey also shows that the deterioration in these indicators has been accompanied by declines in health, education and nutrition indicators. Encovi data, for instance, indicates that the percentage of people eating two or less meals per day has risen from $11.3 \%$ in 2014 to over $25 \%$ in 2019. Regular assistance to education centers - for subjects between the ages of 3 and 24 - has declined from $73 \%$ in 2014 to $70 \%$ in 2019. This decline has been particularly sharp on the 18-24 age group, for which regular assistance was of $47 \%$ in 2014 and has fallen to $25 \%$ in 2019.

The magnitude of the country's migration exodus is hard to pin down, among other things due to the fact that it continues to increase rapidly, rendering even very recent estimates outdated. As of August 2020, United Nations (UN) agencies 
estimated the stock of Venezuelan refugees and migrants at 5.2 million persons, based on data from national immigration authorities and other sources. ${ }^{6}$ This series is almost surely an underestimate of the current stock of emigrants for at least two reasons. One is that there is a lag in reporting, so that current estimates typically incorporate national estimates that can be more than a year old. The second one is that most of the national data sources used omit any estimate of undocumented migration, while some also exclude refuges and asylum seekers. ${ }^{7}$

One particular difficulty in assessing the magnitude of emigration has to do with dual nationalities. According to the population division of the UN Department of Economic and Social Affairs (DESA), around one million Colombian nationals lived in Venezuela by 2017 (United Nations, 2017). Because Colombia applies the ius sanguinis concept and both countries admit dual nationalities, Rodríguez (2018a) estimated that as many as 4.5 million persons recently residing in Venezuela either have or can claim Colombian nationality. These return migrants, who would enter Colombia using a Colombian passport, would not typically be counted as Venezuelan emigrants, and their number could be large enough so as to significantly affect the aggregate totals. In fact, it is logical to infer that it is precisely these Colombian nationals who would have greater propensity to return in the midst of the country's economic crisis.

Given the inherent limitations of national statistics for capturing Venezuelan emigration, some researchers have resorted to alternative methodologies. The methodologies range from using national surveys to enquire as to the number of family members living abroad to using the geolocation of social media postings by accounts originally posted in Venezuela. These methods give higher estimates, putting the total stock of emigrants higher than 5 million persons by mid-2018. ${ }^{8}$

In other words, Venezuela's exodus is the largest refugee crisis documented in Latin America to date and, according to some estimates, could be similar in magnitude to the 5.6 million refugees produced by the Syrian conflict, the world's largest refugee crisis in the past three decades.

The scale of Venezuela's collapse is staggering. However, only a few academic studies have been written attempting to identify its causes. Researchers and commentators have pointed to the role of macroeconomic imbalances,

\footnotetext{
6. Available at: <https://r4v.info/es/situations/platform>.

7. The February 2019 joint statement by United Nations High Commissioner for Refugees (UNHCR) and International Organization for Migration (IOM) does not give details on methodology, but a mid-2018 report by IOM, which put the migrant stock at $2.7 \mathrm{mn}$ persons, used data from receiving countries, which in some cases went back to 2016 . All sources in that report, except for Colombia, omit estimates of irregular migration.

8. An August 2018 study by local polling company Consultores 21 estimated the stock of Venezuelan emigrants at 5.6 million persons, while Hausmann, Hinz and Yildirim et al. (2018) estimated that 2.9 million persons had left the country in the one-year period before April 2018. Santos (2018) employed Facebook data to estimate migration and concluded that the Venezuelan diaspora stood at 4.9mn people as of November 2018.
} 
microeconomic distortions, and economic sanctions as possible drivers. However, similar drivers have been present in comparable economies and, while having an adverse effect on growth, have not generated collapses of the magnitude that we observe in Venezuela. As a result, consensus on an overarching explanation of the causes remains elusive.

\section{DIAGNOSIS: UNDERSTANDING THE DRIVERS OF THE COLLAPSE}

\subsection{Data sources}

Starting in late 2015, Venezuela's government systematically reduced the amount of official data on economic performance that was made publicly available. The data blackout extended to all significant macroeconomic indicators, including figures for GDP, external accounts and inflation. On May 2019, the central bank released a mostly complete suite of data, covering most indicators up to the end of 2018. GDP, for instance, was released up until the third quarter of 2018, while external debt and balance of payment data runs up to the end of the year. Monthly inflation figures were released covering up to April 2019. Data published by other government agencies - such as poverty and demographic data published by INE or fiscal accounts published by the Ministry of Finance - remain severely outdated, and the Central Bank has not indicated whether it plans to resume regular publication nor has it provided a timetable of data releases. The most recent poverty and inequality data published by INE is for the first half of 2015, while the most recent fiscal statistics published by the Ministry of Finance date from 2013 for the central government and from 2011 for the consolidated public sector.

In some cases, missing data was reported to international agencies despite not being published domestically. This is the case with fiscal data presented in the 18 -K forms filed by the government before the Securities Exchange Commission. These have provided us with official fiscal statistics up to 2016.

During Venezuela's 3-year information blackout, private consultants, non-governmental organizations (NGOs) and other organization stepped in to fill in some of the missing data. The opposition-controlled National Assembly now publishes inflation and economic activity data, constructed using methods that aim to replicate the Venezuelan Central Bank's methodology. Torino Economics, the economics research department of a United State investment bank focused on Latin America, publishes a compendium called the Red Book twice a year, which compiles data estimates constructed using alternative data sources and econometric models. 
In this report, we will use official data for our historical series whenever it is available, unless otherwise indicated. For estimates of key macroeconomic aggregates where there is no official data available or when we are referring to forecasts of future evolution of the economy, we use the IMF's figures. For more disaggregated data not available from the IMF or central bank we use the Torino Economics Red Book as our main source of data. In some selected cases, such as our discussion of inflationary financing, we bring in alternative data sources as indicated.

Given the need to use data estimates and forecasts intensively, it is necessary to be cautious in interpretation of many of our results. Data that is estimated based on models of the economy can appear to confirm hypotheses that may themselves be built into the models used to construct the data. We believe the results sketched out in this paper to be robust to data assumptions, but will also be careful to point out instances where this may not be the case.

\subsection{Oil dependency and the import crunch}

In order to understand why the Venezuelan economy contracted by as much as it did, we have to start with one of its basic characteristics: it is an economy that is, for all relevant purposes, completely specialized in oil. Oil accounted for $95.6 \%$ of the country's exports in 2012 - just before the collapse started. ${ }^{9}$ Of the remainder, chemical products, metals and mining accounted for another $2.9 \%$ of total exports, reflecting the economy's comparative advantage in petrochemicals and energy-intensive steel and aluminum.

Evidently, its low level of diversification makes the economy highly vulnerable to external shocks. A simple correlation between changes in oil prices and GDP growth delivers a 0.51 correlation between 2000 and 2016, with oil price variations accounting for $26 \%$ of changes in GDP. In principle, it is possible for countries to insure against this volatility by undertaking precautionary savings, tapping capital markets and adopting countercyclical macroeconomic policies. As we discuss in further detail below, Venezuela proved unable to do any of these during the most recent oil boom.

There are two channels through which oil activity affects the economy: through its direct effect on oil GDP, and through its indirect effect on non-oil GDP. Most observers of the Venezuelan economy are surprised when they learn that oil accounts for only around $15 \%$ of GDP. ${ }^{10}$ In order to understand why this

9. By 2018 , this ratio had fallen to $91 \%$, largely as a result of the collapse of oil production and an increase in gold exports.

10. The average share of oil to total GPD in national accounts data from $1 Q 97$ to $1 Q 19$ is $14.3 \%$. That share had declined through the 2000s, so that in the last four quarters of available data (2Q18-1Q19) it averages $12.1 \%$. 
is the case, we have to remember that most economic activity in Venezuela - or in any oil exporting country, for that matter - is not oil production in and of itself but the production of non-tradable and import competing goods made possible through the imports that are paid for with the country's oil export revenues.

Figure 1 lays out the key causal links implicit in the model of the economy that will guide our reasoning. Data constraints impede a full estimation of a computable general equilibrium model, yet the flowchart shows the key channels that would be modelled for such an economy. ${ }^{11}$ The country's oil sector plays a determinant role in the economy, precisely because it is for all practical effects the country's only provider of foreign exchange. ${ }^{12}$ The availability of foreign exchange is influenced by world oil prices, as well as by the oil industry's productive capacity. It is worth noting that, in contrast to many other economies with more complex trade and investment linkages with the rest of the world, the bulk of the effect of the global economy on Venezuela's economy can be summed up in variations in oil prices. ${ }^{13}$

The economy pays for its imports using its export revenues plus any net financing flows. This link is very important because it highlights how the economy's key growth driver can be affected when the country loses access to international capital markets as took place in 2017. Some of these imports go to the oil sector - mainly intermediate inputs such as diluents for the country's heavy crudes - while the remainder goes to the non-oil sector.

Greater availability of imports affects non-tradables production positively. In fact, a great part of the non-tradables sector, such as retail, contains activities that are necessary for the sale of imports to the domestic market. Even in the case of some tradables, such as car assembly, the imported component of production is so high that the sector cannot function adequately without adequate import provision. Partly for this reason, the effect of import availability on tradables production, which one would typically expect to be negative (scarcer imports serve as a stimulus to import substitution) is ambiguous. Here, the functioning of the price system plays an important role. For example, price caps on tradable goods during an adverse terms of trade shock will impede the depreciation of the currency from having a positive effect on local tradables output, and thus reinforce the contractionary effect of the shock. Ultimately, output of both tradables and non-tradables goods, as well as consumption imports, are the key determinants of living standards. At the same time, production of both sectors is set apart to finance investment in both the oil and non-oil sectors, determining future capacity of production.

11. For a computable general equilibrium model of the Venezuelan economy, see Rodriguez and Sachs (1999).

12. From 2012 to 2018, oil exports accounted for $94.8 \%$ of all exports.

13. As a result of the massive migration exodus discussed in section 1, the country has begun to receive significant remittance inflows. Nevertheless, according to official statistics, these numbers are still minor relative to oil revenues, with net current transfers at USD 2.0bn in 2018 (up from USD 0.2bn in 2016), as opposed to USD 29.8bn in oil exports. 
FIGURE 1

Macroeconomic interrelations in the Venezuelan economy

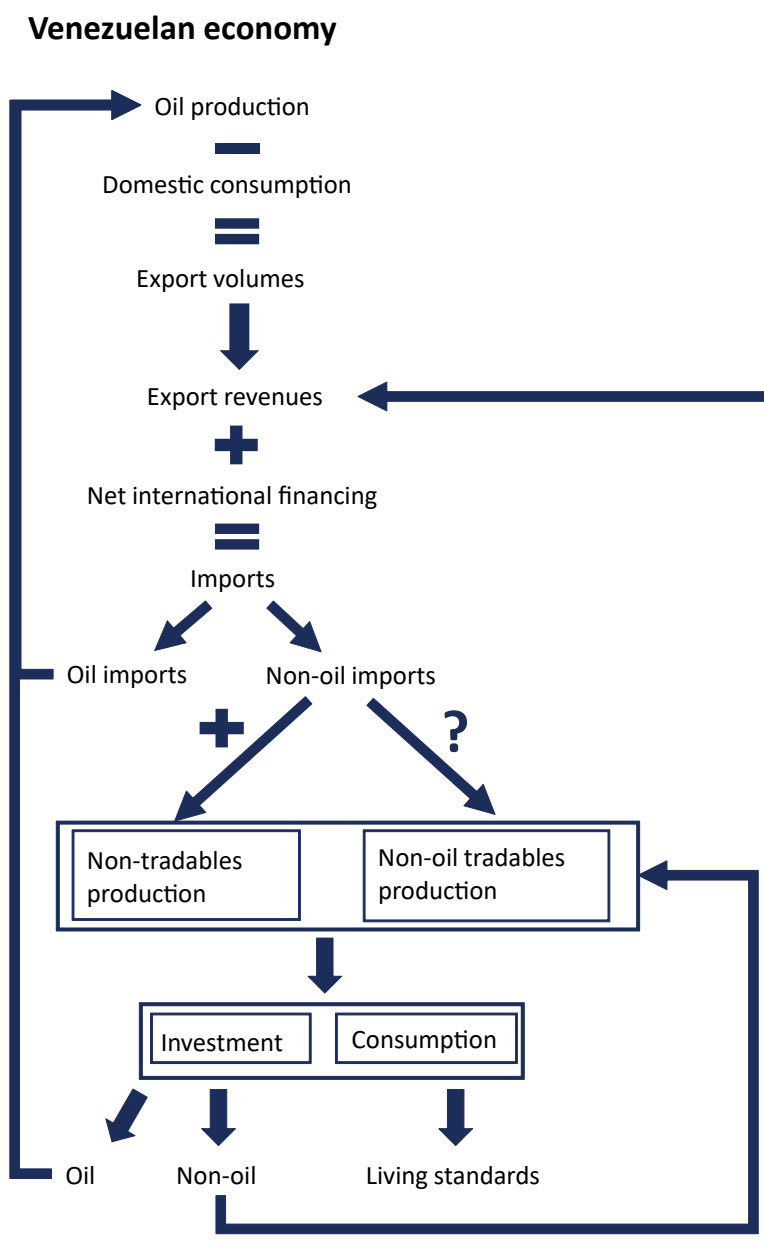

Global economy

Oil prices

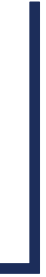

Elaborated by the authors.

The bottom line is that in this economy domestic output is going to be determined to a very great extent by changes in oil exports - resulting both from world oil prices or the oil sector's productive capacity - and the economy's access to international financing. When these channels are open - as was the case from 2004 to 2012 - the economy will expand, and when they are closed - as was the case from 2014 on - then the economy will contract.

The determinant impact of import capacity on domestic output reflects the fact that while most of the economy's production is not oil, almost all of it is made possible by oil since it would not exist without the oil revenues that 
fund it. This fact is evidenced in the data by the strong relationship between imports and GDP. Chart 2 plots the relationship between non-oil GDP growth and non-oil import growth using quarterly year-on-year growth rates. There is a strong positive relationship, with a full $78 \%$ of the variation in non-oil growth explained by variations in imports. The elasticity of non-oil GDP growth to non-oil import growth is 0.24 , implying that a change of $4.3 \%$ in imports will bring about a change of $1 \%$ in economic growth. ${ }^{14}$ Some of the extremes in this figure correspond to the 2002-03 oil strike. In 1Q03, the strike resulted in a $42.8 \%$ year over year $(\mathrm{y}-\mathrm{o}-\mathrm{y})$ decline in oil production and a $71.1 \%$ decline in imports; consequently in 1Q04, imports recovered $56.5 \%$ in y-o-y terms against the low levels registered one year before. ${ }^{15}$ Data for the four quarters of 2016 also shows y-o-y falls upwards of $70 \%$, with corresponding non-oil GDP falls between $14 \%$ and $21 \%$.

\section{CHART 2}

\section{Quarterly non-oil GDP and non-oil imports (y-0-y growth rates)} (In \%)

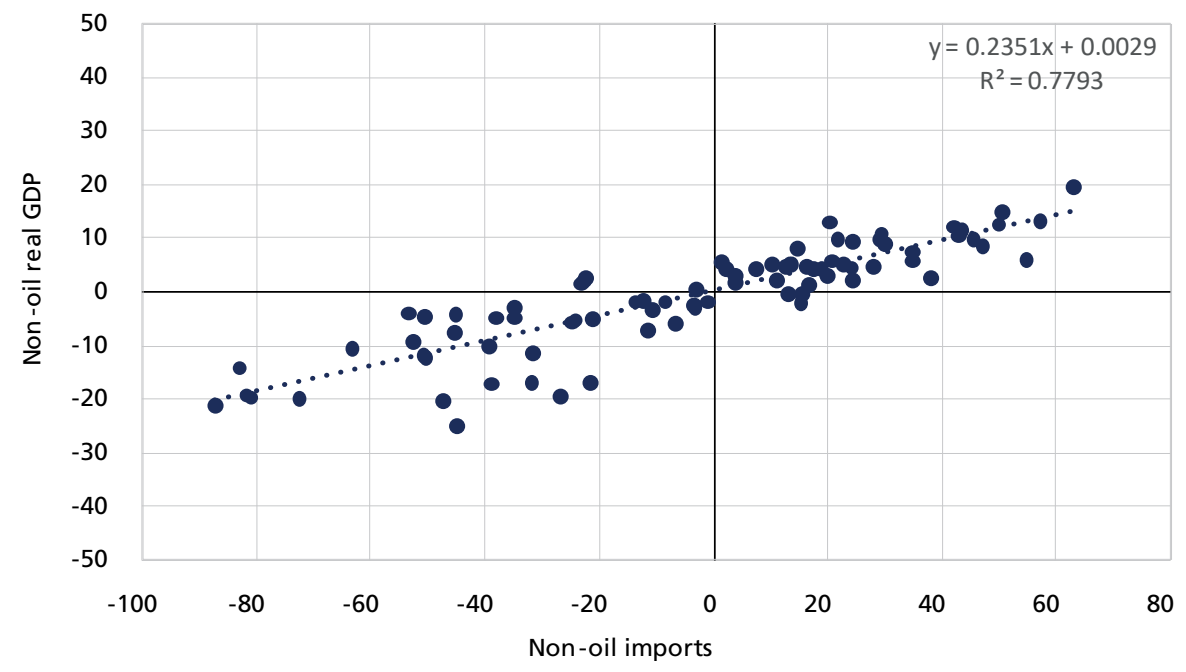

Source: BCV.

The historical relationship between imports and non-oil growth explains a large part of the collapse in Venezuela's economy up until 2018. Venezuelan non-oil imports fell by $88.8 \%$ between 2012 and 2018. The 0.24 elasticity

14. To be more precise, a change of 4.3 log points reduction in imports will bring about a 1 log-point reduction in GDP For low percentages, log points are a good estimate of percentage point variations, so that a 4.3 log point variation is equivalent to a $4.4 \%$ change. For larger percentage, the approximation is much poorer.

15. Excluding these two outliers, and restricting the data to $3 Q 15$, results in an elasticity of non-oil GDP growth to non-oil import growth of 0.22 , with $75 \%$ of the variation in non-oil growth explained by variations in imports. 
estimate from chart 2 would imply that we should have expected a contraction of $40.3 \%$ in output as a result. This is not too different from the resulting contraction that took place, of $45.5 \% .{ }^{16}$ In other words, the data suggests that almost nine-tenths of the observed decline in GDP can be explained as a result of the import collapse.

An alternative approach to estimate the role of imports in the economy's collapse is by augmenting the traditional growth accounting frameworks to include the role of imported goods. Broadly speaking, there are two ways to do this. One of them is by positing a direct effect of imports on total factor productivity. In fact, a number of recent contributions have estimated a direct effect of imported inputs, distinct from that of domestically-produced inputs, on firm-level productivity. This literature is premised on the idea that there is an externality in the use of imported inputs that generates a contribution to productivity over and above its marginal product. ${ }^{17}$

A second approach is by specifically modelling an aggregate production function tailored to an economy that is fully specialized in oil production. As discussed by Hausmann and Rodríguez (2011), in a fully specialized economy - i.e., one that produces just one tradable good - with an open capital account, the endogenous capital stock will be directly related to the magnitude of resource rents. This does not happen in an unspecialized economyone that produces more than one tradable good - since shocks to resource rents can be accommodated by shifts of productive resources to the other tradables sector. In other words, the high dependence of a completely specialized economy to its external revenues is a consequence of the fact that in such an economy, there is no alternative tradables sector to pick up the slack. ${ }^{18}$

Table 3 summarizes the effects of both decompositions applied to the 2013-2018 level. The difference between both approaches has to do with the role attributed to other factors of production and the assumptions on the elasticity of output to imports. In the full specialization approach, imported inputs enter the production function through their effect on the capital stock, and thus have an elasticity equal to the capital share. In the externality approach, the elasticity needs

\footnotetext{
16. Note that because the estimate is of a log-elasticity, then we need to compare log variations. The $88.4 \%$ non-oil import decline is equivalent to a 215 log-point decline, while the $48.1 \%$ non-oil GDP decline is equivalent to a 66 log-point decline. The ratio of these two changes is .30, slightly higher than the .23 historical elasticity estimate. 17. Hulten (1978) shows that TFP at the aggregate level consists of the residual of aggregate production growth on the share-weighted growth of primary (and not intermediate) inputs. Recall that payments to intermediate inputs (as opposed to payments to capital and labor) are not part of value-added. Therefore, their inclusion in the aggregate production function is premised on the idea that there is some externality based on their use, such as learning from the superior foreign technology embodied in the inputs, quality-ladder effects from higher quality imports, or variety effects from an enlarged set of available inputs. See Halpern, Koren and Szeidl (2015); Kasahara and Rodrigue (2008) and Ahn and Choi (2016).

18. See also Rodriguez and Sachs (1999) and Hausmann and Rigobon (2003) for other developments of this idea.
} 
to be assumed or separately estimated - we use estimates from microeconomic studies in the literature. Also, since the capital stock is fully endogenous in the full specialization approach, no separate component is estimated for it.

Between 2013 and 2018, Venezuela's economy contracted at an average annualized rate of $12.7 \%$. However, the decline in the country's capital stock can account for only 1.2 percentage points, or $9.6 \%$, of that decline, while the contraction in the labor force can account for an even lower 0.5 percentage points ( $4.1 \%$ of the total decline). In the conventional total factor productivity (TFP) calculation, we would conclude that the remaining 10.9 percentage points, or $86.3 \%$ of the decline, is due to productivity losses.

However, once we augment the production function to include the role of imported intermediates, we can attribute most of this decline to the import contraction. Using the externalities approach, we estimate that the $23.6 \%$ annual import contraction contributed a full 5.6 percentage points to the annual GDP contraction, or $44.1 \%$ of it, with 5.3 percentage points attributable to pure TFP variations and the remaining 1.7 percentage points again due to capital and labor variations.

TABLE 3

GDP growth decomposition by alternative methods

(In \%)

\begin{tabular}{|c|c|c|c|c|c|c|c|c|c|}
\hline & & \multicolumn{4}{|c|}{ Conventional method } & \multicolumn{2}{|c|}{ External effects } & \multicolumn{2}{|c|}{$\begin{array}{c}\text { Complete } \\
\text { specialization }\end{array}$} \\
\hline & & GDP & Capital & Labor & TFP & Imports & TFP & Imports & TFP \\
\hline \multirow{3}{*}{ 1999-2013 } & Growth & 3,3 & 5,0 & 2,8 & - & 10,4 & - & 10,4 & - \\
\hline & Contribution & 3,3 & 1,9 & 1,7 & $-0,3$ & 2,5 & $-2,8$ & 4,0 & $-2,4$ \\
\hline & Percentage contribution & 100,0 & 58,0 & 52,0 & $-10,1$ & 74,5 & $-84,5$ & 120,7 & $-72,7$ \\
\hline \multirow{3}{*}{ 2013-2018 } & Growth & $-12,7$ & $-3,2$ & $-0,8$ & - & $-23,6$ & - & $-23,6$ & - \\
\hline & Contribution & $-12,7$ & $-1,2$ & $-0,5$ & $-10,9$ & $-5,6$ & $-5,3$ & $-9,1$ & $-3,1$ \\
\hline & Percentage contribution & 100,0 & 9,6 & 4,1 & 86,3 & 44,1 & 42,2 & 71,5 & 24,4 \\
\hline
\end{tabular}

Source: Hoffmann (2000); IMF; BCV.

The complete specialization approach, which treats the capital stock as endogenous, ends up attributing a much larger share of variation to the import contraction -9.1 percentage points, or $71.5 \%$ of the total - with only 3.1 points (24.4\% of the total) corresponding to "genuine" (i.e., not related to imports) changes in productivity.

Table 4 shows the results of adjusting the above calculations to take into account a measure of human capital, using mean years of schooling from Organização das Naçóes Unidas para a Educação, a Ciência e a Cultura 
(UNESCO) as adapted by UNDP (2018) as a proxy for the stock of human capital. Doing this substantially raises the contribution of human capital to growth in the 99-13 period, from accounting for 1.7 points to 3.9 percentage points of the growth rate, and thus strengthening the conclusion that the country must have experienced negative TFP growth $(2.5 \%$ a year). In other words, given the amount of investment in human capital as reflected in improving education levels, we would have expected a much greater growth boost during the oil boom period; that it didn't happen could only be explained for as a result of the deterioration on the country's overall productivity (including, possibly, the quality of education which is not adequately reflected in the mean years of schooling indicators).

TABLE 4

GDP growth decomposition by alternative methods: including the effects of human capital

(In \%)

\begin{tabular}{|c|c|c|c|c|c|c|c|c|c|}
\hline & & \multicolumn{4}{|c|}{ Conventional method } & \multicolumn{2}{|c|}{ External effects } & \multicolumn{2}{|c|}{$\begin{array}{c}\text { Complete } \\
\text { specialization }\end{array}$} \\
\hline & & GDP & Capital & $\begin{array}{l}\text { Human } \\
\text { capital }\end{array}$ & TFP & Imports & TFP & Imports & TFP \\
\hline \multirow{3}{*}{$1999-2013$} & Growth & 3,3 & 5,0 & 6,3 & - & 10,4 & - & 10,4 & - \\
\hline & Contribution & 3,3 & 1,9 & 3,9 & $-2,5$ & 2,5 & $-4,9$ & 4,0 & $-4,5$ \\
\hline & Percentage contribution & 100,0 & 58,0 & 117,5 & $-75,5$ & 74,5 & $-150,0$ & 120,7 & $-138,2$ \\
\hline \multirow{3}{*}{ 2013-2018 } & Growth & $-12,7$ & $-3,2$ & 0,0 & - & $-23,6$ & - & $-23,6$ & - \\
\hline & Contribution & $-12,7$ & $-1,2$ & 0,0 & $-11,4$ & $-5,6$ & $-5,8$ & $-9,1$ & $-3,6$ \\
\hline & Percentage contribution & 100,0 & 9,6 & 0,2 & 90,2 & 44,1 & 46,1 & 71,5 & 28,2 \\
\hline
\end{tabular}

Source: Hoffmann (2000); IMF; BCV; UNDP.

Adjusting for human capital, however, makes little difference to the 2013-2018 decomposition, given that there was essentially no improvement (in fact, there was a small deterioration) in the human capital proxy of mean years of schooling. It is possible, however, that these results could be altered if the recent waves of emigration have affected schooling in ways that are not captured by the UNESCO data, which is based on households surveys.

In sum, various methodologies coincide in attributing a large fraction of the blame for the economy's collapse to declining imports. A regression based approach tells us that imports can account for $77.9 \%$ of the decline, while a growth accounting framework attributes to them between $44.1 \%$ and $71.5 \%$ of the decline, with productivity and disinvestment acting as secondary factors and labor force contraction playing a minor role. 
In the 1999-2013 period, the Venezuelan economy grew by an average $3.3 \%$ per year, with growth in capital accounting for 1.9 percentage points and labor for 1.7 percentage points, thus leaving productivity losses of 0.3 percentage points under the conventional approach $(2.5 \%$ under the human capital adjustment). The externalities approach shows that productivity accounted for a 2.8 percentage points loss to GDP growth while the specialization approach shows a 2.4 percentage points loss (4.9 and 4.5 percentage points, respectively, under the human capital adjustment).

These figures compare poorly to those of regional peers. Araujo, Feitosa and Silva (2014) estimated average 2.3 percentage points in growth attributable to productivity gains for Latin America and the Caribbean during the 2001-2010 period, with only Jamaica presenting productivity losses (of 0.002 percentage points). ${ }^{19}$

To identify the import collapse as a key explanatory factor does not yet provide us with a satisfactory explanation for Venezuela's growth implosion, because imports are clearly an endogenous variable determined by several other factors. Furthermore, import reductions are not necessarily always a bad thing: import-substitution development strategies, for example, seek to generate a reduction in import dependence through policies aimed at stimulating the industrial sector. In order to understand why import reductions had such a negative effect in Venezuela, we must understand more about what caused it.

\subsection{Import collapse, exports, and savings}

It is not hard to find the proximate reason for the import collapse. Venezuela could buy much less from the rest of the world in recent years because it was selling much less to the rest of the world than in the not-too-distant past. Between 2012 and 2018, exports fell from USD 98bn to USD 34bn, a 65\% decline. This two-thirds decline in export revenue meant that the country simply did not have the resources to continue funding its import needs.

Here it is important to underline the relevance of the country's productive structure. Not all economies suffer as strongly from an external shock to export revenue as Venezuela. For example, between 2014 and 2016, Colombia suffered a negative terms of trade shock due to the same decline in oil prices that hit Venezuela, with Colombian exports falling by $42 \%$ and the economy's imports contracting by $28 \%$ as a result. Oil accounted for around $50 \%$ of Colombia's exports at the time, so the magnitude of the shock was somewhat less than that of Venezuela, yet still quite sizable. Nevertheless, Colombia's economy did not

19. Excluding Venezuela. The study estimates Venezuelan TFP for the period at 2.98 percentage points. Our own calculations show a much lower 0.4 percentage points contribution of TFP to GDP growth in the 2001-2010 period. 
go into recession. Growth slowed from $4.7 \%$ in 2014 to $1.4 \%$ in 2017 , and the country did not suffer a single quarter of GDP contraction.

One of the reasons why Colombia did not contract as strongly in response to the import decline is that its export and import-competing sectors were able to expand as a result of the depreciation of the real exchange rate that came with the negative shock. In 2017, when the economy was slowing down the most, non-oil exports were growing by $18 \%$, while domestic agriculture had accelerated to $5.5 \%$ - almost double its $2.9 \%$ growth of 2014 . Colombia's ability to produce other tradable goods, and the capacity of its domestic industry to raise production to substitute for more expensive imported goods, served as an insurance for the economy against negative terms of trade shocks.

Likewise, in Venezuela one can point to the extreme levels of oil dependence, as well as the private sector's inability to react to changes in relative prices among other things due to the administration's byzantine system of price and exchange controls - as key explanatory factors in the collapse. In other words, one can make the point that the reason for the collapse is not so much in having received a negative shock but in the economy's inability to adapt to it, which is in itself a reflection of poor policies and institutions.

Nevertheless, while we consider these caveats about productive structure and the lack of a functioning price system to be generally valid, it is also true that the data suggests that the economy's collapse is not all that different from what we would have expected given the economy's structural characteristics, as embodied in the estimates of the import-elasticity of growth based on data from the 1997-2015 period. In other words, the data suggests that it is not a recent worsening in the policy or institutional policy framework that has driven the collapse; rather, the Venezuelan economy of the past decades was unprepared for suffering a shock of this magnitude.

There are two other important caveats to this story. The first one is that countries with high terms of trade volatility typically build up large reserves levels in order to insure against negative shocks. However, this did not happen during Venezuela's oil boom, despite the fact that the country enjoyed the largest positive terms of trade shock of major Latin American economies. International reserves were at USD 14.8bn at the end of 1998, when oil prices hit historic lows. By September of 2014, when oil prices started declining, they were only USD $21.3 \mathrm{bn}$, an amount that is actually $0.4 \%$ lower than the 1998 figure in inflation-adjusted terms. And, while the government did build up some non-reserve savings in off-budget funds (not included in the reserve figures), it also racked up significant liabilities. Therefore, the broader measure of net public sector external assets as captured by the public sector's international investment 
position rose by just USD $10.0 \mathrm{bn}$ in that period (or $1.2 \%$ of the country's cumulative oil export earnings during those years).

To drive home the comparison, it is instructive to note that Saudi Arabia had the same level of reserves as Venezuela in 1998 (USD 14bn) but by September of 2014, had seen them increase to USD 745bn (Saudi Arabia has similar oil reserves to Venezuela, though it produces around three times as much oil). As a result, Saudi Arabia was able to accommodate to the negative shock in oil prices by spending around USD 250bn of those reserves, something that Venezuela was unable to do.

The other caveat refers to the fact that there is a distinction between accounting for the decline in living standards since 2013 - in which we have highlighted the role of the contraction in oil revenues and imports - and accounting for the low level of living standards of Venezuelans after the collapse. As we have discussed previously, Venezuela saw very poor productivity growth during the 1998-2018 period; it also failed, in contrast to most other oil exporters, to increase production of oil during a period of high prices. Between 1998 and 2016 , Venezuela's oil production fell by $21.5 \%$, while OPEC' ${ }^{20}$ output rose by $20.5 \%$, leading Venezuela's share of OPEC production to fall from $11.0 \%$ to $7.2 \%$. Because of those two facts, Venezuelans' living standards were lower than they could have been at the peak of the boom, and the ensuing collapse pushed the majority of the economy into conditions of deprivation.

\subsection{Determinants of export collapse}

Since oil accounts for almost all of the country's exports, then in order to understand the country's export collapse, we need to focus on what happened to the oil sector. Chart 3 shows that oil exports track oil prices relatively well up until the first half of 2016. This means that the country was exporting a relatively constant number of barrels and that the decline in sales before 2016 was caused by the fall in prices. However, from the second half of 2016 onwards, oil prices began to recover, but oil exports didn't. The reason is that Venezuelan oil production had begun to fall, so that the country was selling less and less oil to the rest of the world. Chart 4 shows this phenomenon more directly, tracing how Venezuelan oil production plummeted by two-thirds between 2016 and 2019. ${ }^{21}$

\footnotetext{
20. Organization of the Petroleum Exporting Countries.

21. There are several data series for oil production in Venezuela. All of them show a break in trend in the second half of 2017, as well as in the initial months of 2019 and 2020. Most series show stability in the 2008-2015 period, but there is a difference in the pre-2016 trends. Data produced by secondary agencies tends to show stability in the 2008-2016 while data produced by the Venezuelan government tends to show a decline. Most oil industry experts are distrustfu of the official data, which becomes highly volatile in the post-sanctions period. It is possible that the pre-2016 decline in the official series is an artifact of changes in the magnitude by which the government decides to exaggerate output.
} 


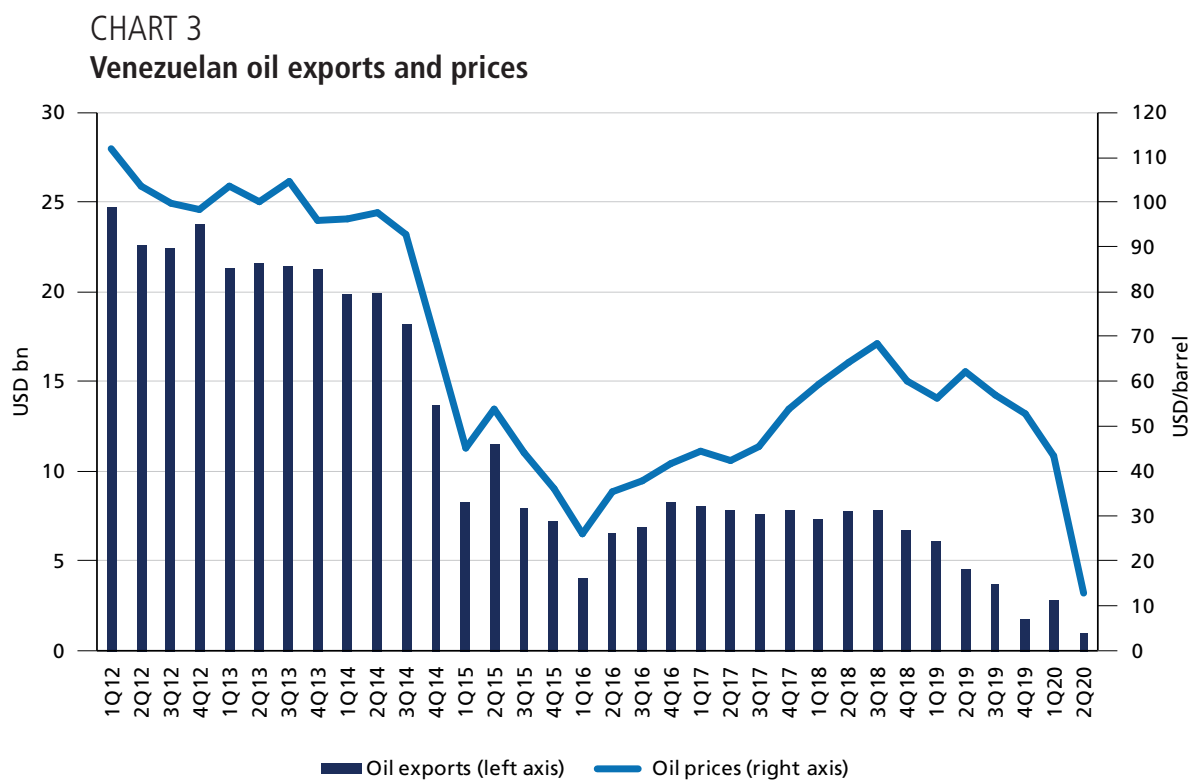

Source: Bloomberg; BCV; Torino Economics.

Chart 4 also suggests that there are three distinct periods in the evolution of Venezuela's oil production data. Production remains relatively stable at around $2.3 \mathrm{mn}$ barrels up to December of 2015. At the start of 2016, it begins to decline and falls at rate of $1.0 \%$ per month. Then, from September of 2017 onwards, the rate of decline accelerates, averaging $3.1 \%$ over the next 16 months. Finally, from January 2019 on it suffers an even steeper drop, declining at an average rate of $5.5 \%$ over the nineteen-month period (last available data is from Jul 2020).

Pre-2015: production stability amid relative underperformance. Venezuelan oil output, as measured by OPEC secondary sources, exhibits a decline in the first decade of the Chávez administration (1999-2008) and then stabilizes at around $2.3 \mathrm{mbd}$ over the next eight years (2008-2016). Since Venezuela is an OPEC member, some of this variation responded to enforcement of quotas, so it is more appropriate to look at its relative performance to other cartel members. Output went from representing $10.5 \%$ of total OPEC production in 1999 to $7.5 \%$ in 2015. Thus, Venezuela underperformed other cartel members, even despite the fact that some of them - namely Iraq and Libya - underwent armed conflicts during this period, which hampered their production growth. 
CHART 4

Venezuela and Colombia oil production (2013-2020)

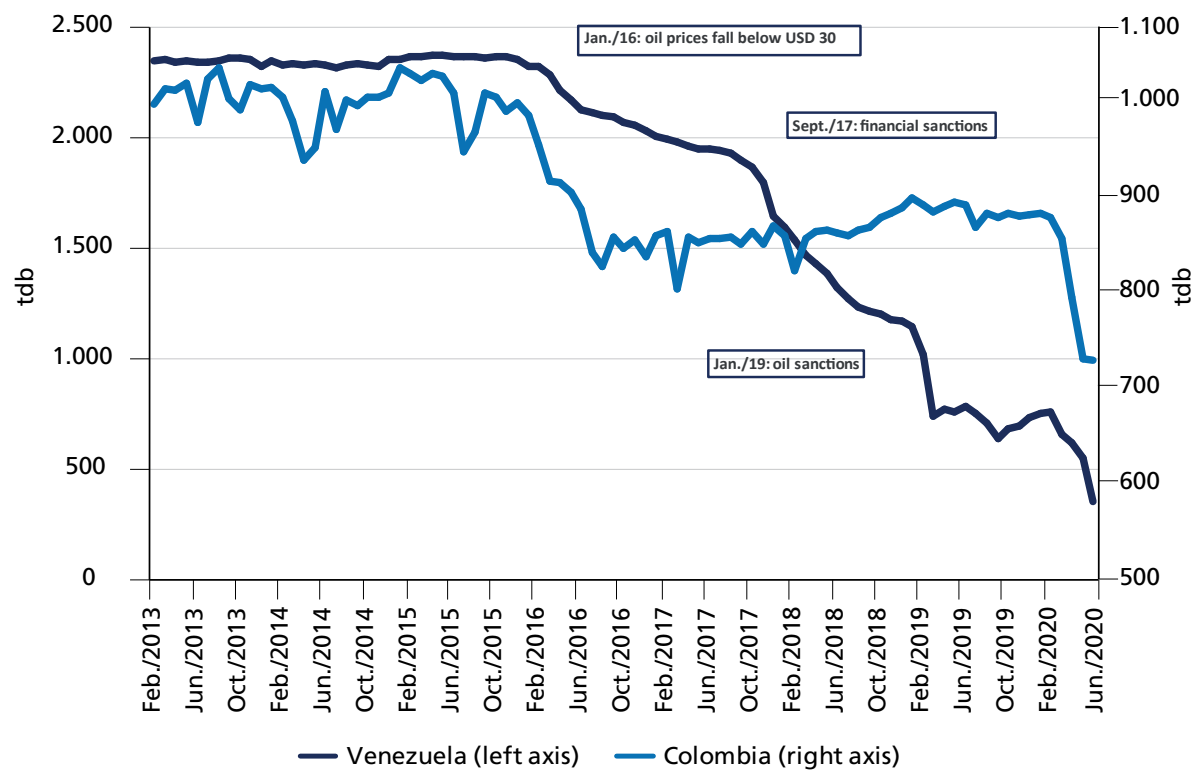

Source: OPEC; United States Department of Energy; Colombian National Hydrocarbons Agency.

Venezuela's oil sector performance is even worse when measured against its potential. Venezuela is home to $20 \%$ of the world's oil reserves but - even before the recent collapse in oil production - accounted for around $2 \%$ of its output. Venezuela produces less than $1 \%$ of its proven reserves annually, as opposed to an OPEC average of $2.6 \%$ and a world average of $5.0 \%$. Saudi Arabia, with reserves of 266bn barrels, manages to produce 10.5 million barrels per day, while Venezuela, with 302 billion barrels in reserves, has been unable to produce more than 3 million barrels per day during the past two decades.

Venezuela's inability to take advantage of its oil wealth can be traced in part back to Hugo Chavez's decision to impose high taxes on the oil industry in order to fund social expenditures. In 2001, the government approved a controversial reform of the Hydrocarbons Law significantly raising tax contributions. While the reform raised the royalty rate while lowering the income tax rate, it also scrapped a preferential tax regime that had been granted to private sector investors during a 1990s oil sector opening. In 2007, the government also required private sector investors to accept the conversion of their contracts into minority stakes in joint ventures (JVs) that would be controlled by the state-owned oil company, Petróleos de Venezuela S.A (PDVSA). Then, in 2009, the government moved one-step further, nationalizing hundreds of assets of service providers of the oil 
industry, including docks, shipyards and vehicles and absorbing the employees of these firms into PDVSA's payrolls.

PDVSA was not just being saddled with numerous assets that it had no knowledge of how to manage; it was also taking on an increasing amount of debt. In order to fund higher spending, pay for many of the nationalizations while defending an overvalued currency, the government not only used the revenues from higher oil prices, but also took up greater levels of debt. The government's external debt rose from USD 29bn when Chávez took office to USD 138bn by 2017. This included USD 60bn of debt owed directly by PDVSA.

All of this meant that PDVSA was not able to maintain the investment commitments it needed in order to develop the use of its oil reserves. The government launched several plans for expanding oil production, but PDVSA was never allowed to invest the resources necessary to carry them out. For example, the 2005 Plan Siembra Petrolera laid out an investment plan of USD 77bn in investments over six years to double oil production that barely materialized; by 2012, the government expanded the plan to USD 257bn, $81 \%$ of which was expected to be made by PDVSA. Although the amounts invested grew significantly from 2003 to 2014, some indicators of investment outcome, such as the number of wells completed, did not trend upwards, suggesting increased inefficiencies, as well as possibly leakages to corruption, in the company's investment activities.

2016-2017: prices plunge and production begins to decline. As oil prices fell, PDVSA's revenues collapsed from USD 122bn in 2014 to 48bn in 2016. The company slashed investment, cutting it from USD 24.5bn in 2014 to USD $12.1 \mathrm{bn}$ in 2016, the lowest level seen by the firm in one decade. Wells completed and active rigs, two leading indicators of future production, also fell drastically. Not surprising, oil production soon followed suit, with output falling by 324tbd, a decline of $14 \%$, during 2016 .

Yet the decline observed in oil production in 2016 was not completely out of the ordinary given the external environment. Recall that oil prices collapsed between 2014 and 2016, putting many oil producers at risk. What made PDVSA vulnerable was the combination of high-cost production in some of its western fields and its high level of indebtedness. Faced with similar conditions, many high-cost leveraged producers were forced to cut back investment and suffered losses in production. As chart 4 illustrates, other Latin American producers saw similar trends up until mid-2017. For example, oil output in neighboring Colombia, part of whose oil industry was also highly leveraged, saw production fall by similar levels during 2016, as did those of Argentina (which shared a similar policy framework during more than a decade) and Mexico (whose 
politicized national oil company is often compared to Venezuela's. However, oil production in these countries either stabilized (Colombia and Argentina) or continued to decline gradually (Mexico) as oil prices began recovering, but went into free fall in Venezuela.

Late 2017-2018: production decline accelerates after financial sanctions, default. The acceleration in the rate of decline in oil production that we see after 2017 could be due to the lagged effects of the decline in investment rates seen after 2014. But the fact that it took place even in a context of recovering oil prices suggests that other factors may be at play. Furthermore, even though investment fell, it remained at levels that were not too different from those seen, say, in 2009-2010 after a similarly pronounced decline in oil prices.

The magnitude of the post-August drop in production caught many observers by surprise. Writing in April of 2017 IPD Latin America - perhaps the most prominent oil consultancy covering Venezuela - predicted in its "worst case" scenario a decline of $13 \%$ in production in 2017 and an annual average rate of decline of $6 \%$ in the subsequent three years. By contrast, production fell by $19 \%$ in 2017 and by $25 \%$ in the first eight months of 2018 .

There are other potential suspects for the decline in output after late 2017. The most obvious one is the imposition of United States financial sanctions in late 2017. President Donald Trump's Executive Order 13.808, issued on August 25 of 2017, barred United States persons from providing new financing to the Venezuelan government or PDVSA. Although the order carved out allowances for commercial credit of less than 90 days, it stopped the country from issuing new debt or selling previously issued debt currently in its possession.

The Executive Order is part of a broader process of what one could term the "toxification" of financial dealings with Venezuela. During 2017, it became increasingly clear that institutions who decided to enter into financial arrangements with Venezuela would have to be willing to pay high reputational and regulatory costs. This was partly the result of a strategic decision by the Venezuelan opposition, in itself a response to decisions that opponents to the government argued undermined the rule of law and democracy. Particularly important breaking points were the October 2016 decision to invalidate the opposition's request for a constitutional recall referendum, the March 2017 Supreme Court decisions that transferred legislative powers to the presidency on the argument that the Legislature was in contempt for refusing to abide by prior Court decisions, or the July 2017 holding of elections for a Constitutional Convention that, according to the opposition, had been unconstitutionally convened.

For example, in early 2017 the president of the opposition-controlled National Assembly wrote several letters to international banks warning them that if 
they lent money to Venezuela they would be not only violating Venezuelan law, but also favoring a government that was recognized as dictatorial by the international community. ${ }^{22}$ Angry Venezuelans gathered to protest outside of the offices of Goldman Sachs when its asset management arm purchased USD 2.8bn of bonds from the Venezuelan government at a high discount through an intermediary in May of the same year. By the time that sanctions were approved in August, Venezuela had all but lost access to international financial markets as a result of the combination of continued poor policies and the toxification of its finance.

Sanctions had the effect of definitively closing the door on any possibility of a Venezuelan debt restructuring. The Venezuelan government announced in November 2017 the creation of a commission to restructure Venezuela's debt, but that commission to this date has produced no results, largely because there seems to be no legal way in which United States investors can negotiate with it. ${ }^{23}$ The adoption of financial sanctions was followed by a letter of guidance issued by the Financial Crimes Enforcement Network (FinCen) on September 20, 2017, warning financial institutions that "all Venezuelan government agencies and bodies, including [state-owned enterprises] SOEs appear vulnerable to public corruption and money laundering" (FinCen, 2017) and recommending that several transactions originating from Venezuela be flagged as potentially criminal.

These restrictions impacted Venezuela's oil industry in several ways. First and most evidently, loss of access to credit stops you from obtaining financial resources that could have been devoted to investment or maintenance. As is often the case with event-study analysis, it is difficult here to build the counterfactual, as one can argue that Venezuela's unsustainable policies would have led it to lose market access in 2017 even if its finance hadn't become toxic. However, countries that lose market access typically have the possibility of regaining it after entering a debt restructuring process, a door that was closed to Venezuela after the Executive Order. ${ }^{24}$

22. See, for example, the April 18, 2017 by National Assembly President Julio Borges to the CEO of Deutsche Bank (Romero-Castillo, 2017).

23. Although there is no legal impediment for institutions in other countries to participate in such a restructuring, non-United States creditor groups have shied away from any action that would impose restrictions on their capacity to do business in the United States and that would leave them with bonds that would not be tradable in United States markets.

24. Some observers have argued out that given the quality of macroeconomic management, a successful restructuring was not likely under the Maduro administration. This argument again illustrates the difficulty of building a counterfactual, as doing so requires staking out a position on what government policies would have looked like in this scenario. However, for the purposes of the link between oil output and access to finance, what is most important is the ability of PDVSA, instead of the sovereign, to refinance some of its debts, particularly those that are related to service providers that directly impact on production. The fact that PDVSA was in fact refinancing its debt with suppliers through the issuance of New York law promissory notes up until the adoption of sanctions suggest that this channel would have remained open had sanctions not been imposed. 
But there are also more direct links with oil production. For example, one of the most effective mechanisms that PDVSA had found to raise production in recent years was the signing of financing agreements in which foreign partners would lend to finance investment in a JV agreement as long as they could pay the loan from the JV's production. Likewise, before sanctions were imposed, PDVSA had begun to refinance a significant part of its arrears with service providers through the issuance of New York law promissory notes. The Executive Order put an end to both of these arrangements.

Despite the coincidence in timing between the adoption of sanctions and the decline in output, other hypotheses have been proposed as potential driving factors. One of them is the fact that Venezuela defaulted on its external debt at the end of 2017, a default that had been widely expected by markets. Since a disorderly default will lead a country to lose access to international capital markets, it has some of the same consequences of financial sanctions. This has led some observers to claim that the financial sanctions were redundant. ${ }^{25}$

A second hypothesis for the decline relates to the growing militarization of the country's oil industry, presented by Morales (2019). On November 26, 2017, General Manuel Quevedo, who had no previous industry experience, was tapped to head the country's national oil firm PDVSA, in the midst of a broad-ranging corruption investigation that led to the jailing of 95 industry executives, including two former PDVSA presidents. According to proponents of this hypothesis, the disarray caused by these decisions was the main driver of the post-2017 production collapse.

Recent research has looked more systematically at the causes of the decline using cross-national and industry level data and modern statistical techniques and has found that the 2017 sanctions have indeed been an important. Rodríguez (2019a) shows that Venezuela's post-2017 collapse in oil production is one of the largest in the history of oil-producing countries and comparable only to those experienced by countries undergoing wars or oil strikes. He uses synthetic control methods to build an estimate of how Venezuelan oil production would have evolved in the absence of oil sanctions and finds that the difference between the counterfactual and observed production - which in this method serves as an estimate of the effect of sanctions, amounts to 797 thousand barrels per day, of USD 16bn at today's oil prices.

25. In any case, whether one believes that the ultimate culprit of the output decline is the adoption of financial sanctions or the default on debt, both explanations emphasize the loss of access to international capital markets as a key driving force. In this sense, for our purposes of diagnosis, the important conclusions - on which both explanations would agree - is that the loss of access to financing contributed to the production decline. Furthermore, from a policy standpoint, both explanations would also support the claim that the lifting of financial sanctions is fundamental to economic recovery. 
Furthermore, the evolution of oil production within the country's oil industry also lends support to the sanctions hypothesis. Output in JVs between national oil company PDVSA and Chinese and Russian companies, who's financing was not affected by United States financial sanctions, saw production increase or remain stable while output was collapsing in the rest of the oil industry. Similarly, sanctions-exempt foreign subsidiaries of PDVSA such as the United States based refining company CITGO, saw revenues and output increase, while non-sanctions-exempt ones such as Colombia-based fertilizers company Monómeros, swung into large losses. The data is also not supportive of the militarization hypothesis - the share of military officers in PDVSA's board today is in fact lower than it was in 2001, when oil output was almost four times today's level.

2019: production plummets as United States bans oil trade. On January 28, 2019, president Donald Trump included state-owned oil company PDVSA on the list of Specially Designated Nationals (SDNs) maintained by the Treasury Department's Office of Foreign Assets Control (Ofac). This designation effectively bars any United States nationals from doing business with PDVSA or any of its affiliates. Since PDVSA is the majority stakeholder in oil JVs in Venezuela's oil sector, it effectively constitutes a prohibition of purchases of Venezuelan oil, as well as of exports of oil products to Venezuela.

The sanctions were adopted just weeks after the United States government decided to recognize National Assembly president Juan Guaidó as the nation's legitimate interim president, thus withdrawing recognition of the government of Nicolás Maduro. As a result, bank accounts of the Venezuelan government and Central Bank were transferred to the Guaidó administration. Guaidó appointees also have the ability to request recognition by courts to their appointments to the board of state-owned corporations and have been able to do so effectively; while they do so, the accounts of these entities remain blocked (Cohen, 2019).

As a result of this decision, Venezuela lost access to the United States oil market and financial system. At the same time, United States authorities have extracted commitments from other key partners (namely India, the most important destination for Venezuelan oil after the United States) not to increase oil purchases from Venezuela. The sanctions are estimated to lead to losses of revenue of around USD 10bn, or about a third of Venezuela's 2018 oil exports. ${ }^{26,27}$

26. At the time of the announcement of sanctions, White House national security adviser John Bolton said that these would generate USD $11 \mathrm{bn}$ in lost export proceeds over 2019 and block him from accessing PDVSA assets worth USD 7bn. See Spetalnick and Ellsworth (2019).

27. On its January 7, Torino Economics forecasted oil exports of USD 20.7bn for the year. Due to the effects of United States sanctions and blackouts during the first quarter, the firm revised its forecast to USD 11.6bn on its May 6 report. 
In contrast to the financial sanctions, there is more - though not total consensus on the thesis that oil sanctions have led to a sizable decline in oil revenues. ${ }^{28}$ Export data produced by Bloomberg based loading of vessels in PDVSA docks in Venezuela and the Caribbean, as well as ship-to-ship transfers, shows total loadings dropping by $34.9 \%$ between January and June of 2019 . Exports to the United States have fallen to zero, while exports to India and China have not significantly increased. Several alternative output estimates also show similar declines to that displayed in chart 4.

As expected, the decline in export revenues and impediments in accessing the United States and European financial systems have led to an additional import plunge. Total imports, which had stabilized in 2018, were 37.2\% down in 2019, according to data from 31 trading partners collected by Torino Economics.

\subsection{The slide into hyperinflation}

Venezuela's economic implosion was exacerbated by a rapid inflationary acceleration. Despite a history of persistent high inflation, the country had never before been racked by the hyperinflations which did hit other countries in the region in the late 80 s and early 90s. Instead, the Venezuelan economy had stayed in the range of low to middle double-digits since the mid-1980s, last seeing single-digit year-on-year inflation on April of 1986. Nevertheless, there had been only two instances of accelerations into triple digit inflation: for one month in 1989 and for seven months in 1996, both of these taking place after large exchange rate adjustments.

In late 2015, prices began accelerating, breaking triple digits in July of 2015 and reaching $181 \%$ by year-end. After that, the picture becomes murkier, due to significant divergence in official and unofficial estimates. Annual Consumer Price Index (CPI) increased at rates of $274 \%$ in 2016, 863\% in 2017 and $130,060 \%$ in 2018 according to data reported by the central bank, but private sector estimates put it between $320 \%$ and $698 \%$ in 2016, between 1.4 and 4.2 thousand percent in 2017 and between 65 thousand and 1.7 million percent for 2018. Despite the large variation in estimates, all figures had surpassed the conventional 50\% monthly threshold of the classic Cagan (1956) definition of hyperinflation by the end of 2018 .

Hyperinflations tend to be accompanied by severe recessions: the median country in hyperinflation grows by 7.2 percentage points less than a country with price stability (Saboin, 2018). Hyperinflations erode the real value of savings and

28. However, Hausmann and Muci (2019) have argued that the decline in oil production after January should be traced to the country's blackouts. However, Rodriguez (2019a) points out that blackouts were concentrated in March; by May there were no national blackouts and production had nevertheless continued to fall. See Morales (2019), Bahar et al. (2019), Weisbrot and Sachs (2019a, 2019b) and Rodriguez (2019b) for other contributions to this debate. 
reduce the size of the financial sector; they can therefore have long-lasting effects on growth even after the hyperinflation ends (Reinhart and Savastano, 2003). They also impair the capacity of agents to make long-run economic plans and thus have direct effects for the efficiency of resource allocation.

TABLE 5

Official and unofficial measurements of the annual inflation rate (In \%)

\begin{tabular}{lccccc}
\hline & \multicolumn{5}{c}{ Inflation rate y-0-y } \\
\cline { 2 - 5 } & 2015 & 2016 & 2017 & 2018 & 2019 \\
\hline BCV & 180,9 & 274,4 & 862,6 & $130.060,2$ & $9.585,5$ \\
National Assembly & $\mathrm{N} / \mathrm{A}$ & $\mathrm{N} / \mathrm{A}$ & $2.616,0$ & $1.698 .514,3$ & $7.374,4$ \\
CENDA - Basic Goods Basket & 321,8 & 522,3 & $1.811,8$ & $170.180,7$ & $7.606,6$ \\
Torino Economics Model & $\mathrm{N} / \mathrm{A}$ & 698,2 & $4.205,5$ & $103.548,8$ & $\mathrm{~N} / \mathrm{A}$ \\
Torino Economics (Octavio Arepa Index) & 419,2 & 319,8 & $1.455,9$ & $298.576,7$ & $\mathrm{~N} / \mathrm{A}$ \\
Bloomberg - Café con Leche & $\mathrm{N} / \mathrm{A}$ & $\mathrm{N} / \mathrm{A}$ & $1.718,2$ & $199.900,0$ & $6.566,7$ \\
Relative PPP - implied inflation & 381,8 & 281,8 & $3.422,6$ & $65.449,8$ & $10.376,6$ \\
\hline
\end{tabular}

Source: BCV; National Assembly; Centro de Documentación y Análisis para los Trabajadores (CENDA); Torino Economics; Bloomberg Obs.: N/A = not available; PPP - Purchasing Power Parity.

Hyperinflations are invariably preceded by prolonged bouts of monetization of large budget deficits, and Venezuela was no exception. Over the seven-year period ranging from 2012 to 2019 , the consolidated public sector deficit averaged $15.7 \%$ of GDP and was never lower than $9.5 \%$ of GDP for any single year (table 6). At the start of that period, the government was able to sterilize the effect on the money supply by depleting its foreign asset holdings (chart 5); thus, inflation did not accelerate that rapidly. However, by the end of 2015, the bulk of these assets holdings was depleted and it proved impossible to contain the monetary impact of the large deficits, leading prices to skyrocket.

Inflationary financing was paying for a large part of the deficit. As shown in table 7 , real seigniorage - the amount of real resources that the government was able to capture from money printing - provided the government with around 7 percent of GDP in financing between 2013 and 2015. On average, the government obtained 5.8\% of GDP in those years from depletion of external assets. Even as these external assets shrank, so did the magnitude of the economy. Thus, even in 2017, the USD 4.6bn depletion of international reserves and off-budget fund holdings, despite being small in absolute terms relative to that of earlier years, represented $4.6 \%$ of GDP in financing. 


\section{CHART 5}

Liquid asset holdings (2008-2018)

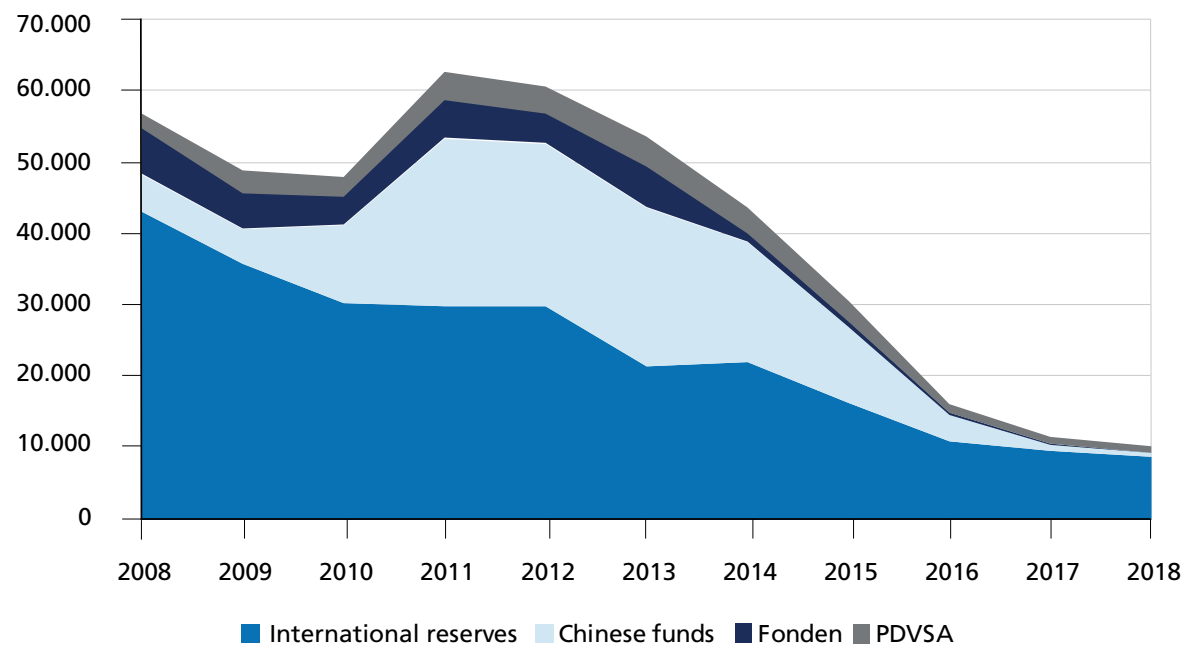

Source: Ministry of Finance; BCV; PDVSA; Torino Economics.

TABLE 6

Fiscal accounts

(In \% of GDP)

\begin{tabular}{|c|c|c|c|c|c|c|c|c|c|c|c|c|c|}
\hline & & 2008 & 2009 & 2010 & 2011 & 2012 & 2013 & 2014 & 2015 & 2016 & $2017 \mathrm{E}$ & $2018 \mathrm{E}$ & $2019 \mathrm{E}$ \\
\hline \multirow{4}{*}{ Central government } & Revenues & 32,2 & 23,6 & 24,1 & 28,2 & 28,0 & 31,8 & 34,8 & 35,6 & 39,5 & 34,7 & 32,1 & 8,7 \\
\hline & Expenditure & 33,7 & 29,1 & 28,6 & 33,2 & 33,5 & 33,9 & 35,6 & 33,9 & 32,2 & 45,1 & 43,5 & 15,9 \\
\hline & Primary surplus & 0,1 & $-4,1$ & $-2,6$ & $-1,6$ & $-2,4$ & 1,4 & 2,0 & 3,3 & 8,0 & $-8,6$ & $-11,3$ & $-7,2$ \\
\hline & Financial surplus & $-1,6$ & $-5,5$ & $-4,5$ & $-5,0$ & $-5,6$ & $-2,1$ & $-0,9$ & 1,7 & 7,3 & $-10,5$ & $-11,4$ & $-7,3$ \\
\hline \multirow{4}{*}{ Restricted public sector } & Revenues & 41,3 & 27,1 & 26,4 & 37,3 & 30,7 & 34,6 & 43,0 & 29,8 & 24,1 & 35,9 & 36,3 & 11,6 \\
\hline & Expenditure & 44,7 & 36,0 & 38,2 & 46,5 & 47,7 & 49,8 & 52,1 & 44,0 & 47,9 & 40,1 & 48,2 & 18,7 \\
\hline & Primary surplus & $-1,6$ & $-7,3$ & $-9,6$ & $-6,4$ & $-13,1$ & $-11,0$ & $-5,2$ & $-11,9$ & $-16,4$ & 15,8 & $-10,2$ & $-6,6$ \\
\hline & Financial surplus & $-3,5$ & $-8,9$ & $-11,8$ & $-9,2$ & $-17,0$ & $-15,3$ & $-9,0$ & $-14,1$ & $-23,7$ & $-4,2$ & $-11,9$ & $-7,1$ \\
\hline \multirow{4}{*}{$\begin{array}{l}\text { Expanded central } \\
\text { government }\end{array}$} & Revenues & 41,9 & 26,2 & 27,9 & 38,8 & 36,4 & 39,2 & 39,5 & 43,9 & 40,5 & 36,0 & 34,2 & 12,5 \\
\hline & Expenditure & 41,6 & 35,7 & 31,2 & 42,9 & 41,5 & 42,0 & 42,5 & 42,4 & 38,7 & 51,9 & 50,8 & 20,5 \\
\hline & Primary surplus & 2,1 & $-8,0$ & $-1,4$ & $-0,5$ & $-1,7$ & 1,0 & 0,4 & 3,6 & 3,1 & $-13,0$ & $-8,8$ & $-5,7$ \\
\hline & Financial surplus & 0,3 & $-9,5$ & $-3,3$ & $-4,1$ & $-5,1$ & $-2,8$ & $-3,0$ & 1,5 & 1,9 & $-15,9$ & $-16,6$ & $-7,9$ \\
\hline \multirow{4}{*}{ Expanded public sector } & Revenues & 50,9 & 29,7 & 30,3 & 48,0 & 39,1 & 42,0 & 47,7 & 38,1 & 25,2 & 37,2 & 38,5 & 12,8 \\
\hline & Expenditure & 48,9 & 42,4 & 40,5 & 51,9 & 51,6 & 54,6 & 57,2 & 52,6 & 54,3 & 46,9 & 63,2 & 25,5 \\
\hline & Primary surplus & 4,0 & $-11,1$ & $-8,0$ & $-1,0$ & $-8,5$ & $-8,2$ & $-5,2$ & $-11,8$ & $-21,2$ & 11,3 & $-15,4$ & $-9,9$ \\
\hline & Financial surplus & 2,0 & $-12,7$ & $-10,2$ & $-4,0$ & $-12,5$ & $-12,6$ & $-9,5$ & $-14,5$ & $-29,1$ & $-9,7$ & $-24,7$ & $-12,7$ \\
\hline
\end{tabular}

Source: Torino Economics; BCV; PDVSA; SEC; Bloomberg. 


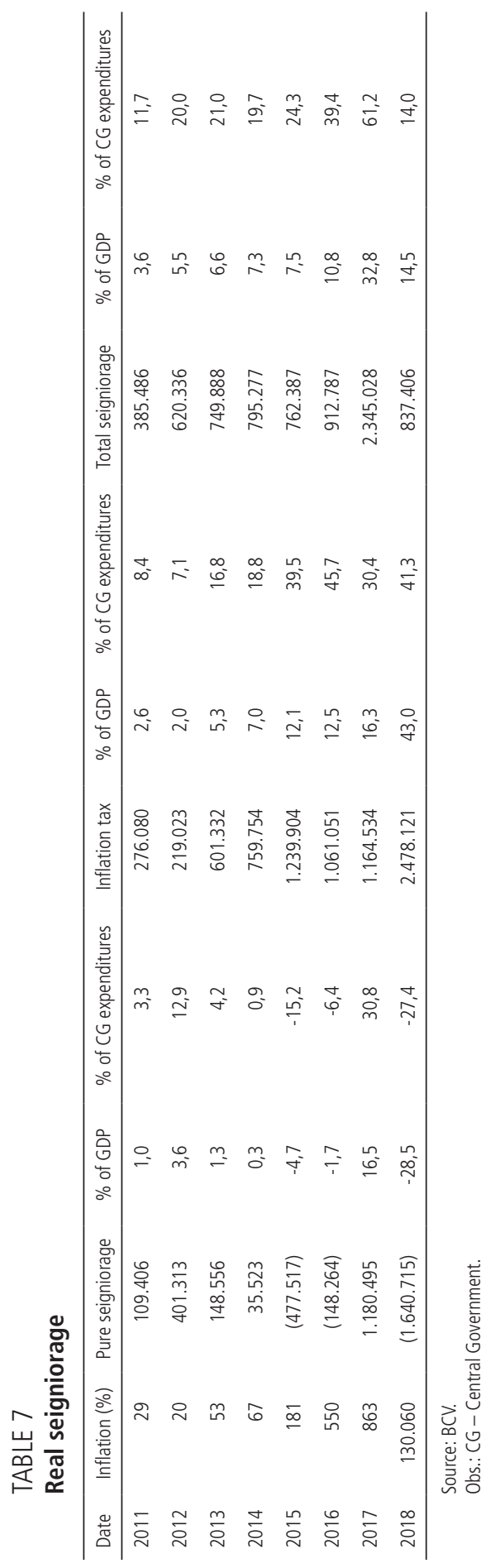


Part of the dynamics of hyperinflation entail a decline over time in the capacity of the government to fund its spending. As with any other tax, the inflation tax has a Laffer curve associated with it: after a certain threshold, more taxes mean less revenue. At very high rates of inflation, people will try to hold less money, and the decline in real money holdings limits the government's capacity to finance itself by covering that money demand. As shown in table 7 , by the end of 2018, that amount had fallen to $14.5 \%$ of GDP, down from $32.8 \%$ in 2017.

This is also the reason why the fiscal data show a decline in the deficit to $6.1 \%$ of GDP in 2018. As the government loses the capacity to fund itself via inflation, its attempts to fund spending through money printing become self-defeating. No matter how rapidly the government is expanding nominal spending, if it tries to pay for it via money printing, prices will accelerate so rapidly that real spending will decline. At the same time, however, real tax revenues also fall due to the well-known Olivera-Tanzi effect (the negative relationship between real taxes and inflation due to collection lags), as was documented in Tanzi (1977). Hyperinflation therefore continues even though the government is getting relatively little real financing from money printing.

The fact that both the deficit and real spending levels are low implies that stabilization out of a terminal-stage hyperinflation is not that difficult: anything that stabilizes expectations (such as an exchange rate peg) will raise real revenues and can erase the deficit, at least as long as the government does not try to raise real spending beyond sustainable levels. International evidence suggests that Venezuela is near this point. The longest documented duration of a very high inflation (defined as 12-month inflation higher than 1,000\%) was 39 months for Zimbabwe, which lasted from August of 2006 and 2009. Clausen et al. (2007) found that the median duration of these high inflation episodes was 13 months. Per central bank data, Venezuela has been in high inflation for 16 months, suggesting that its hyperinflationary episode may be close to an end.

The role of expectations reversion, nevertheless, is key for a successful stabilization. This fact was famously recognized in the classic study by Sargent (1981) chronicling the end of four hyperinflations, and has been documented in more recent work. ${ }^{29}$ Typically, the governments that have caused the hyperinflation have in so doing undermined the credibility of their monetary or fiscal commitments and have also become politically weak. Stabilization commonly comes with a change in government, particularly in democracies. In authoritarian systems, they sometimes require a major economic overhaul if there is no change in government, as illustrated by Zimbabwe's 2008 stabilization through dollarization under Robert Mugabe. Governments with weak credibility 
are sometimes successful in producing temporary price stabilizations followed by a resurgence of price acceleration, as was the case of Nicaragua in the late $80 \mathrm{~s}^{30}$

\subsection{Relative prices, the exchange rate and the erosion of market institutions}

As Venezuela was hit by the massive external shock discussed above, one of the mechanisms used by the government to try to tame inflationary pressures was maintaining a stable nominal exchange rate. Venezuela has had exchange controls in place since 2003 yet, until 2012, the government had proved its willingness to adjust to the nominal rate over time that allowed it to avoid very serious misalignments from equilibrium. This was to change in 2013, after which nominal exchange rate adjustments were scant and were far outpaced by inflation.

One way to see how serious the misalignments became is by considering the gap between the official exchange rate and the black market price, also known as the black market premium. The premium averaged $88 \%$ over the $2003-2012$ period; at its maximum in that period, it reached $284 \%$. By the end of 2015 , it had risen to $336 \%$, and by the end of 2017 it had reached a surreal 3,081\%.

As changes in the nominal rate were outpaced by inflation, the exchange rate became strongly overvalued. Not surprisingly, this led to greater rationing of foreign exchange by the government. With such large differentials between official and black market prices, arbitrage activities became tremendously attractive. The government clamped down on these activities by tightening enforcement of price controls - which in many cases led to the arbitrage rents being captured by government inspectors. On November of 2013, the government accused Daka, one of the country's largest electronics retailers in Venezuela, of selling products at more than $1,000 \%$ above cost and ordered the military occupation of the stores. Two months later, the government created a price control supervisory agency, the Superintendencia Nacional para la Defensa de los Derechos Socioeconómicos (SUNDDE), with broad powers to fine violators and set prices. ${ }^{31}$

A negative external shock such as that faced by Venezuela should lead to a depreciation of the real exchange rate, defined as the relative cost of prices abroad relative to those at home and proxied by the product of the nominal exchange rate and the ratio of foreign to domestic price indices. This change helps to increase the returns to producing tradable goods and thus reallocates factors of production towards the production of import-competing and exportable goods, both of which help substitute for the loss of export revenue.

30. See Ocampo (1991).

31. SUNDDE was officially created on January 23, 2014, through the Official Gazette no 40.340 , in accordance with the Organic Law for Fair Prices (República Bolivariana de Venezuela, 2014). 
Venezuela's policy of letting the exchange rate be outpaced by inflation, in contrast, led to an appreciation of the official real exchange rate: it made imported goods less, not more expensive. The government's logic was to try to protect consumers from price hikes. However, it ended up making imported goods very cheap but also extremely scarce. Chart 6 illustrates how, while the equilibrium real exchange rate was depreciating rapidly, the official exchange rate was appreciating. This changes in mid-2018, when the government strongly devalues the currency and maintains it close to the parallel rate; from then on, the data indicate that the currency is actually somewhat undervalued.

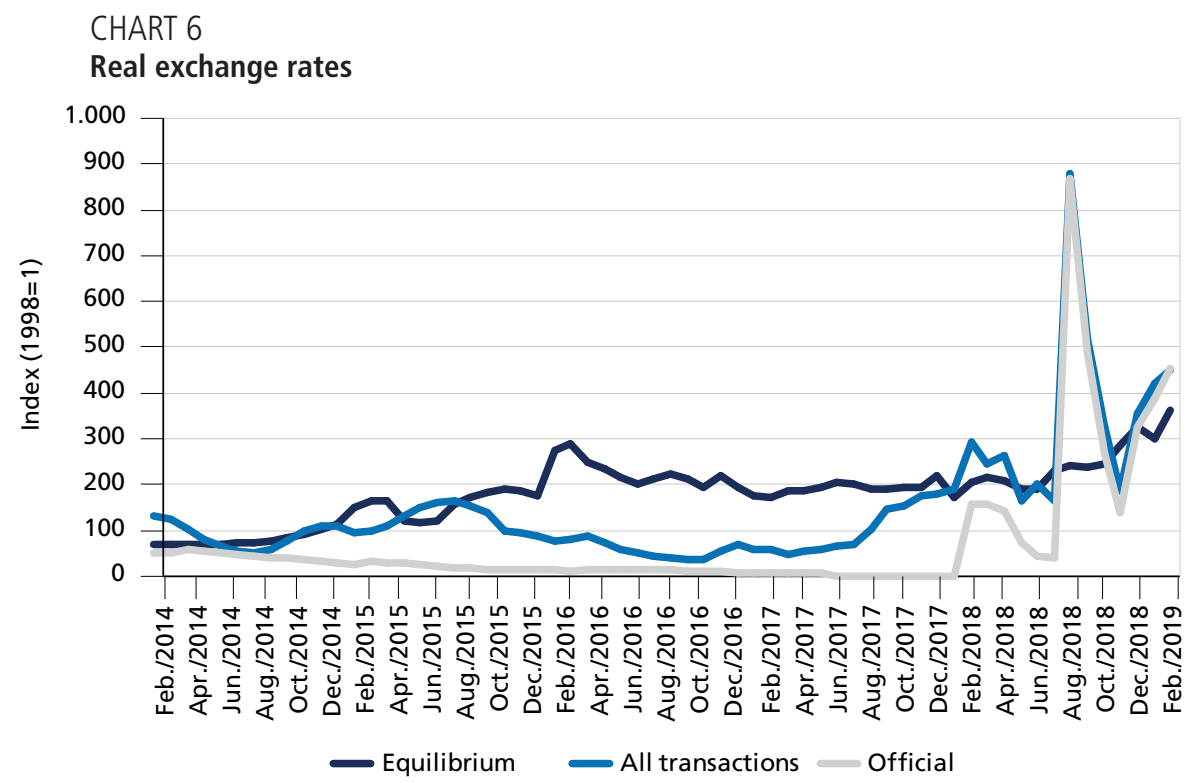

Source: BCV; DolarToday; CENDA; National Assembly; Bloomberg; National Statistics Agencies.

Such a large differential between equilibrium actual prices implied huge arbitrage rents. The government reaction was to attempt to increase enforcement of controls; when this proved insufficient, it intervened directly in resource allocation to ensure that goods were delivered to the intended consumers. On August 2015, Venezuela's government ordered the closure of the border with neighboring Colombia after clashes between the military and smugglers and deported thousands of Colombians blamed for involvement in paramilitary and smuggling activities (BBC, 2015). On April of 2016, the government created the Local Committees for Supply and Production (known by their Spanish acronym CLAP - Comité Local de Abastecimiento y Producción), community-based government committees whose primary role was to distribute food boxes to lower-income Venezuelans, after blaming private sector food 
distribution networks for deviating supplies of subsidized food to higher-income consumers and to contraband. ${ }^{32}$

In assessing the economic effects of increased state participation in the economy, the literature has often focused on how nationalizations undermine incentives for effort and thus lead to declines in productivity, as in Chang, Hevia and Loayza (2018). However, when the government is using state involvement as a tool to enforce out-of-equilibrium prices, there can be potentially more serious general equilibrium effects. If the government can effectively enforce non-market clearing prices, then productive resources will not migrate towards the activities in which they have a higher value marginal product. ${ }^{33}$ In the context of a negative terms of trade shock, enforcement of price controls on the sales of tradable goods reduces the incentives for factors of production to be reallocated towards the production of those goods. But reallocation towards tradable sectors is precisely what the economy needs in order to cushion the blow from lower external revenue.

At the same time, the government's refusal to let the real exchange depreciate contributed to the country's fiscal imbalances. Since the Venezuelan government is a net exporter, then a depreciated exchange rate strengthens fiscal balances. When Venezuelan authorities insisted in maintaining an increasingly overvalued real exchange rate as a response to the negative shock, they were also choosing to run larger budget deficits.

The contribution of relative price distortions to fiscal imbalances goes beyond the direct effect of currency overvaluation on government revenues. A low relative price of tradables also hurts other sources of government revenues - such as import taxes. Additionally, the government's decision to restrain price inflation through controls extended to the other goods and services provided by the government. The price of a liter of low-octane gasoline has remained unchanged since 2016, despite a cumulative $\mathbf{4 5 . 3}$ million percent increase in prices for the economy as a whole.

There has been work at estimating the fiscal incidence of each of these relative price distortions. The effect is contingent on oil prices as well as net exports and the magnitude of misalignments. Rodríguez (2014) estimated the fiscal cost of overvaluation at 2013 prices to range between USD 16.8 and USD $26.2 \mathrm{bn}(7.5 \%$ and $11.7 \%$ of GDP, respectively); the cost of the subsidy to oil

32. "These are the new functions of the CLAP, according to the emergency state decree" (Prodavinci, 2016, our translation).

33. Note that non-market clearing prices by definition will imply an imbalance between supply and demand. If prices are below equilibrium, there will be unsatisfied excess demand. The role of rationing and controls enforcement is to ensure that this excess demand is not filled. 
derivatives rose to USD $12.0 \mathrm{bn}$, or $5.3 \%$ of GDP on that year. Thus, in total, these two subsidies cost between 12.8 and $17.0 \%$ of GDP in 2013, greater than that year's $12.6 \%$ of GDP deficit.

\subsection{Institutional framework and social policies}

Several indicators show a deterioration of the quality of institutions in Venezuela during the last six years. Table 8 presents the trends in selected indices of institutional quality compiled by international organizations and research institutes. The data shows a deteriorating trend on basic institutions across measurements. The World Bank's World Governance Indicators - available up to 2017 - show an average $23.4 \%$ deterioration, with particularly severe declines in its "Voice and Accountability" (which measures freedom of expression, participation among other political freedoms) and "Rule of Law" (property rights, law enforcement, absence of violence, among others) indicators. Likewise, the Heritage Foundation presented a 29.1\% decline in its Index of Economic Freedom and Transparency International a 5.3\% decline in its Corruption Perception Index.

These indicators are not only negative in terms of their evolution, but also show that Venezuela ranks among the lower percentiles of the samples. The World Governance Indicators have Venezuela, on average, just above the $7^{\text {th }}$ percentile, and rank the country as the lowest percentile in its rule of law indicator and 3rd lowest percentile on regulatory quality. Similarly, the Heritage Foundation ranks Venezuela as the second least free country in the world, and Transparency International ranks it at joint 168 worst out of 180 countries in its corruption index, with only 11 countries ranking worse.

The second panel of table 8 also shows the evolution of a number of measures of political institutions, all of which intend to measure the extent to which the country is democratic. All measures show significant deteriorations around 2017, coinciding with the holding of elections for the National Constitutional Convention, the stripping of legislative powers from the National Assembly, and the boycotted 2018 presidential elections.

Government policy in relation to essential public services was significantly revamped from 2003. The traditional approach - under which public services were financed through the central government budget and coordinated through a number of ministries - was complemented, and partially substituted, by a decentralized alternative system, the Sistema Nacional de Misiones Bolivarianas (National System of Bolivarian Missions), which was excluded from the central government budget and thus from parliamentary oversight. 
TABLE 8

Measures of institutional quality and political liberties

\begin{tabular}{|c|c|c|c|c|c|c|c|c|}
\hline Institutional quality indicators & 2012 & 2013 & 2014 & 2015 & 2016 & 2017 & 2018 & 2019 \\
\hline \multicolumn{9}{|l|}{ World Bank - World Governance Indicators (-2.5/2.5) } \\
\hline Voice and accountability & $(0,91)$ & $(0,95)$ & $(1,08)$ & $(1,09)$ & $(1,14)$ & $(1,21)$ & - & - \\
\hline Political stability and absence of violence/terrorism & $(1,03)$ & $(1,08)$ & $(0,85)$ & $(0,98)$ & $(1,02)$ & $(1,18)$ & - & - \\
\hline Government effectiveness & $(1,15)$ & $(1,17)$ & $(1,23)$ & $(1,22)$ & $(1,29)$ & $(1,40)$ & - & - \\
\hline Regulatory quality & $(1,52)$ & $(1,63)$ & $(1,82)$ & $(1,88)$ & $(2,00)$ & $(1,96)$ & - & - \\
\hline Rule of law & $(1,69)$ & $(1,82)$ & $(1,92)$ & $(2,03)$ & $(2,24)$ & $(2,26)$ & - & - \\
\hline Control of corruption & $(1,27)$ & $(1,31)$ & $(1,40)$ & $(1,39)$ & $(1,35)$ & $(1,36)$ & - & - \\
\hline Heritage foundation - index of economic freedom (0/100) & 38,10 & 36,10 & 36,30 & 34,30 & 33,70 & 27,00 & 25,20 & 25,90 \\
\hline Transparency international - corruption percention index $(0 / 100)$ & 19,00 & 20,00 & 19,00 & 17,00 & 17,00 & 18,00 & 18,00 & - \\
\hline \multicolumn{9}{|l|}{ Indices of political institutions } \\
\hline Polity index $(-10 / 10)$ & $(3,00)$ & 4,00 & 4,00 & 4,00 & 4,00 & $(3,00)$ & - & - \\
\hline Freedom house - aggregate score $(0 / 100)$ & 41,00 & 39,00 & 38,00 & 35,00 & 35,00 & 30,00 & 26,00 & 19,00 \\
\hline Varieties of democracy - electoral democracy index (0/1) & 0,41 & 0,36 & 0,33 & 0,31 & 0,30 & 0,26 & 0,24 & - \\
\hline Varieties of democracy - liberal democracy index (0/1) & 0,16 & 0,13 & 0,11 & 0,13 & 0,14 & 0,13 & 0,09 & - \\
\hline
\end{tabular}

Source: World Bank; Heritage Foundation; Transparency International.

Obs.: The World Bank's World Governance Indicators measures 6 dimensions of governance through surveys, and rates each in a range of -2.5 (worst) to 2.5 (best). The Heritage Foundation's Index of Economic Freedom rates a number of key indicators of economic freedom (including protection of property rights, tax burden, government spending and business, trade and labor freedom) to produce an aggregate indicator ranging from 0 (least free) to 100 (most free). Transparency International's Corruption Perceptions Index employs expert assessment and surveys to grade the perceived corruption in countries in a scale of 0 (highly corrupt) to 100 (very clean). The Polity index indicator measures authority patterns and ranges from +10 (full democracy) to -10 (full autocracy). Freedom House reviews several civil and political liberty indicators, and rates countries in a scale ranging from 0 (least free) to 100 (most free). The Varities of Democracy Electoral Democracy Index describes ruler's responsiveness to citizens through electoral means by answering the question: «To what extent is the ideal of electoral democracy in its fullest sense achieved?» and rates countries on a 0 (low) to 1 (high) scale. Similarly, the Varities of Democracy Liberal Democracy Index evaluates the protection of individual and minority rights through the question: «To what extent is the ideal of liberal democracy achieved?», and rates countries in a 0 (low) to 1 (high) scale.

The essential idea behind the system was to skip over traditional bureaucratic management systems and address latent social needs directly; though a bottom-up agile approach capable of fulfilling short-term needs more efficiently than the traditional system. The Misiones system was partially financed by PDVSA, the National Oil Company, through its contributions to the National Development Fund (Fonden). These contributions were originally discretionary but were later formalized through a Windfall Oil Profits Law which mandated PDVSA to transfer to the fund a fraction of oil revenues above a reference oil price. ${ }^{34}$

Early examples of the misiones system focused on expanding the provision of public services, such as education and healthcare, to population groups that 
were previously - due to geographic or social reasons - left unattended by the traditional system. One of the initial flagship programs was Misión Barrio Adentro (Mission into the Neighborhood), which focused on providing primary healthcare within under-privileged areas and shantytowns during its early phases, but later expanded to a more comprehensive approach to the provision of healthcare targeted at under-privileged sectors of the population. Likewise, Misión Robinson and Misión Ribas focused on literacy and adult education for those who had been left out of the traditional education system.

As the Venezuelan government expanded the Misiones program, it also expanded the provision of identity cards and implemented direct cash transfers to incentivize regular participation in some of its programs, which were pointed out as primary conduit of political-motivated employment of public resources for electoral means. ${ }^{35}$ Critics also put into question the quality of the system's services.

According to metrics released by official sources and statements, the effectiveness on the provision of public services improved significantly in the years following the creation of the Misiones system, but these claims have been disputed. At the core of the issue lies the question of whether observed improvements in human development and social spending metrics were a result of changing priorities in the government or just the expected result of higher overall availability of resources within the economy due to the international oil-boom.

A case in point was the October 2005, statement by the Venezuelan government that it had rid the country of illiteracy. The administration issued an announcement at the time, claiming that the country had eradicated illiteracy taking the illiteracy rate to less than $0.1 \%$ of the population. This would have implied that government trainers taught $1.4-1.5 \mathrm{mn}$ persons how to read and write in a span of a couple of years. However, employing INE household survey data, Ortega and Rodríguez (2008) found that Misión Robinson contributed at most to a moderate reduction in the illiteracy rate, while - in some of their specifications - changes in the illiteracy rate were completely explained by economic and demographic trends. Furthermore, they also estimated that there were still around one million persons illiterate after the government had proclaimed the country freed from illiteracy.

Rodríguez (2008a; 2008b) also argued that the share of the central government budget allocated to social spending in the 1999-2006 period had not been significantly different from that of the 1991-1998 period, with the exception of social security spending, which is known to be regressive for Latin America economies. Results are similar when PDVSA social expenditure are taken

35. See Penfold-Becerra (2007). 
into account. There does not seem to have been a significant change in spending priorities during the period, and any increase in social spending registered was on line with what could be expected given the magnitude of the oil boom and the growth of the state that it precipitated.

The country's more recent economic crisis has seen a corresponding collapse in public health. According to data by the World Health Organization (WHO), the infant mortality rate, which had decreased from $2.02 \%$ in 1999 to $1.43 \%$ in 2011, rose to $2.57 \%$ by 2017 , surpassing the average for Latin America and the Caribbean for the first time in the organization's recorded data.

CHART 7

Infant mortality rate

(In \%)

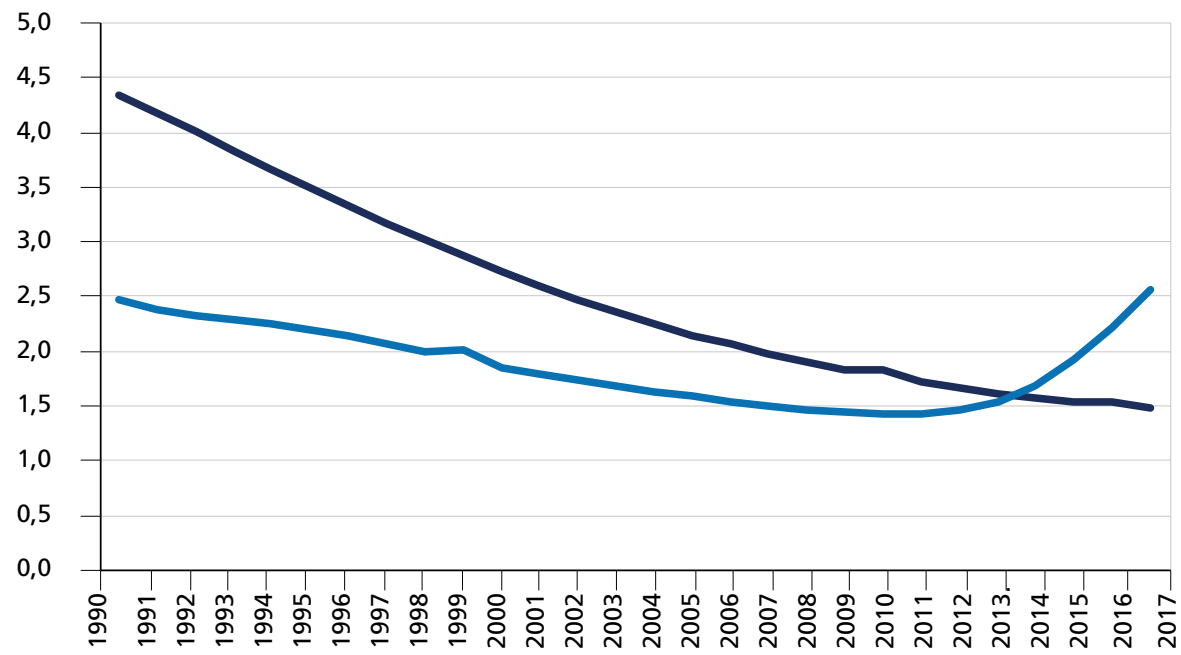

Latin America and the Caribbean Venezuela

Source: WHO.

The incidence of preventable diseases has also seen a significant spike in the last few years, including the outbreak of previously eradicated diseases. A September 2018 report by the WHO shows that Venezuela registered 4,605 cases of measles in 2018, up from a single case between 2008 and 2015 (WHO and PAHO, 2018a). Likewise, the organization reported an outbreak of diphtheria beginning on July 2016; by the time of the September 2018 report, 2,028 suspected cases had been registered, out of which 1,217 were confirmed. These figures are up from no case between 2006 and 2015 (WHO and PAHO, 2018b). Cases of Malaria have risen tenfold, from 36,000 in 2009 to 406,000 in 2017 (Human Right Watch, 2018). One plausible explanation for this deterioration, some of which precedes the economic crisis, is that the shift to emphasis on curative medicine 
through the Barrio Adentro system took resources from the preventive medicine needed to maintain these diseases under control.

The worsening in public health metrics is attributable to worsening infrastructure, equipments, supplies and human capital. The 2019 edition of the Encuesta Nacional de Hospitales (National Hospital Survey), conducted by local NGO Médicos por la Salud, shows that $53.7 \%$ of the country's medical labs were inoperative during the year, as were $58.4 \%$ of $\mathrm{x}$-ray machines, while the amount of available hospital beds fell $23.2 \%$ from 286 to $220 .{ }^{36}$

The report also shows that $67.5 \%$ of the hospitals reported failures in the electricity service, while only $42.9 \%$ of the institutions reported having a fully working reliable power-plant. Furthermore, over $70.2 \%$ of the surveyed hospitals reported failures in the supply of water services and $8 \%$ reported not having access to the service on any day of the week.

The problem is compounded by the lack of qualified personnel. As of late 2017, a survey conducted on medics and medicine students indicated that $40 \%$ of those graduated in the preceding 10 years had already left the country and, out of those remaining, $75 \%$ had some intention to emigrate at some point in the future (Sleinan, 2017).

In 2016, the government created two new social programs, as part of its attempt to create a social safety net and provide a cushion for the crisis. These included the already-mentioned CLAP food distribution program and the Card of the Fatherland, a program that entitled bearers to be eligible for direct cash transfers. The CLAP program consisted in the distribution of government-provided food boxes to the public through community-based organizations, while the Card of the Fatherland was used to electronically distribute discretionary cash subsidies to recipients.

The programs emerge out of two distinct modes of thinking about the Venezuelan crisis. The CLAPs are a government initiative that was born out of dissatisfaction with the ability of the private sector to channel supply of government-subsidized food without adequately controlling contraband and other types of arbitrage. In fact, authorities often blamed some of the main food distribution networks of price-gouging and hoarding and accused the private sector of doing this to generate political instability. ${ }^{37}$

The Card of the Fatherland appears to have its origin in attempts to get the government to move from its reliance on indirect subsidies to a system of direct transfers. A report prepared by an economic mission of the Union of South

36. Available at: <https://www.encuestanacionaldehospitales.com/>.

37. Available at: <http://questiondigital.com/nueva-ofensiva-economica-que-aprendimos-de-la-anterior/>. 
American Countries (União de Naçôes Sul-Americanas - UNASUR) in mid-2016 in fact recommended that the government substitute indirect subsidies to gasoline, electricity and other publicly provided goods and services for a cash transfer mechanism, within the context of a macroeconomic and fiscal adjustment. ${ }^{38}$ Although the government shelved most of the report's recommendations, it did roll out the subsidy card. Given the lack of fiscal adjustment, the transfers were funded through additional deficit monetization.

Both programs reach a large fraction of the population. As of July of 2020, $80.2 \%$ of respondents surveyed by local polling firm Datanálisis claimed to be receiving CLAP boxes, though the number was down from $86.0 \%$ in December of 2018. Other surveys indicate that for most families, boxes do not arrive with sufficient regularity so as to serve as a stable source of food supply. $76.9 \%$ of the population claimed to have the Card of the Fatherland as of February 2020, although only $24.4 \%$ claimed to have received the latest cash transfer from the government through the card. The amount of the cash bonuses has varied significantly over time and is at the government's discretion. Some bonuses are also calculated on the basis of the number of members per household, while others are targeted at particular groups (Patria Blog, 2019).

To the best of our knowledge, no systematic analysis has yet been carried out of the impact of either of these programs. It does seem probable that the CLAP program served to attenuate effects on malnutrition relative to a baseline of no program, although it is unclear whether the deviation of resources towards arbitrage activities is any lower under public sector management than under private sector control of distribution networks. Regarding the Card of the Fatherland program, in contrast, an increase of cash subsidies in the context of high monetized fiscal deficits could only serve to speed inflationary acceleration and real wage declines.

There is another problematic aspect of both of these programs, which is the political use of distribution of benefits. Although there is no evidence of systematic conditioning of benefits on political affiliation, the programs have been used as devices to increase turnout at elections. Due to several electoral events in the last three years being boycotted by part or all of the opposition, conditioning on turnout is in effect conditioning on support for the government. A study of the December 2017 mayoral elections (boycotted by part of the opposition) found that the government handed out food boxes outside of $24.8 \%$ of voting stations and issued Cards of the Fatherland in $12.8 \%$ of them. ${ }^{39}$ This was done at

38. Available at: <https://web.archive.org/web/20190403182259/https://www.panorama.com.ve/politicayeconomia/ Las-propuestas-engavetadas-de-Unasur-y-el-Consejo-Nacional-de-Economia-Productiva-20170118-0105.html>.

39. See Rodriguez and Navarro (2018). 
government party voting stations instead of at government-run installations, thus adding to the problematic blurring of the line between party and state. Outside of $20.8 \%$ of voting stations, party officials asked voters to leave their cards at the party booth and to come and collect it after having voted. Government leaders publicly asked voters to bring their card to the voting booth on election day, despite the fact that the card does not serve as a voting ID. During the 2018 elections, opposition candidate Henri Falcón denounced the use of the Card of the Fatherland for vote-buying by the government and asked the Supreme Court to annul the election results (Pernia, 2018).

\subsection{A brief summary}

The proximate trigger of Venezuela's economic implosion was the plunge in oil prices that began in 2014. But the underlying causes go much further back. Many oil exporting countries suffered the same shock, but Venezuela was one of the worst prepared to handle it, because of its lack of savings under the boom and its over-taxation of and underinvestment in the oil industry. Therefore, the oil bust caused a massive import and economic contraction.

The Venezuelan government made a set of policy choices that impeded macroeconomic adjustment, fueled inflation, deteriorated the efficiency of resource allocation and exacerbated the magnitude of the collapse. Rather than devalue in response to a negative external shock, the government chose to maintain an overvalued exchange rate and couple it with tight enforcement of price and exchange controls. It also decided not to adjust the nominal prices of publicly provided goods and services to keep pace with inflation, thus effectively lowering their relative price and raising the fiscal cost of subsidizing them. It chose to monetize double-digit deficits continuously, depleting external assets and driving the country into hyperinflation.

The government's decision to continue servicing its external debt through this import crunch has also attracted criticism, though the extent through which the government could have avoided default is it had applied policy reforms in time is a source of contention..$^{40}$ Economic sanctions came at the end of this story and appear to have had a negative effect on oil production, although the data is open to several competing interpretations. Nevertheless, financial and economic sanctions impose a significant constraint on the ability of the government to tackle current imbalances. Oil sanctions imposed at the start of 2019 (and those following, particularly in August 2019 and March 2020) have seriously contributed to the exacerbation of the economy's crisis, severely restricting the country's capacity to

40. See Hausmann and Santos (2014) and Rodriguez (2014). 
trade oil in international markets. As a result, growing inventories have forced PDVSA to artificially decrease production to its current levels.

\section{PUTTING VENEZUELA ON THE ROAD TO SUSTAINABLE DEVELOPMENT}

\subsection{Stabilizing the macroeconomy}

In the first section of this work, we discussed why Venezuela's macroeconomic aggregates did not evidence large imbalances in the 2018 data. On the one hand, the country continues to run a current account surplus (USD 5.9bn, or $6.0 \%$ of GDP per the IMF) in order to service sizable debts with Russia, China and selected creditors. On the other hand, hyperinflation has eroded real government spending, lowering the deficit to $6.1 \%$ of GDP. A cursory look at these aggregates may suggest that adjustment should not be that difficult in such an economy.

However, a deeper look reveals a more complex story. The country is certain to suffer a massive decline in its external and fiscal revenues this year. Even if sanctions had not been imposed earlier in 2019 and oil production had stabilized at January levels, oil export revenues would have declined by USD 7.4bn. After the oil sanctions, the decline rises to USD $15.0 \mathrm{bn}$. The decline in export revenues will thus be larger than the sum total of all imports of goods and services last year, implying that the country will not be able to continue running large current account surplus regardless of the magnitude of its import adjustment. In other words, absent external financing, Venezuela will have to undertake another large import adjustment and default on additional key creditors. There is certainly evidence that this has happened: goods imports in 2019 fell by $37.2 \%$ from 2018, falling to a level $45.2 \%$ below the historical minimum for the pre-2016 period (reached in 1990).

Similarly, the decline in oil exports and international trade will signify another contraction of government revenues. As a result, we estimate that under the status quo scenario, real government revenues will fall by $29.6 \%$ (they will remain stable as a share of GDP because GDP will also shrink significantly). Declining export revenue and declining government revenue will make stabilization more difficult than it would have been in the absence of sanctions and continued oil production decline. Therefore, the economy will need significant additional financing in order to avoid another painful adjustment.

These realities will constrain the scope of macroeconomic policy even if the country finds a solution to its political crisis. While oil production tends to recover more rapidly from sanctions-induced collapses, the recovery is never immediate and will in itself require capital. Therefore, avoiding import further import cuts will by itself require substantial levels of international financing. Given that the 
current level of imports appears insufficient to cover the country's basic needs, raising consumption to adequate levels will require even greater financing.

Similarly, the fact that government spending has fallen to only $6.1 \%$ of GDP as a result of the hyperinflation produces what could be termed an illusion of an easy adjustment. Real wages are as of May 2020 (latest inflation print) 83.2\% lower than they were in 2012; in dollar terms, Venezuela's minimum wage is USD 2.5 today, as opposed to USD 227 and USD 250 in neighboring Colombia and Brazil. These real wages appear inconsistent with labor-market equilibrium under moderate labor mobility and stable prices. ${ }^{41}$

Therefore, in order to understand the country's financing needs, we need to understand what its spending requirements would be under reasonable wages. Table 10 presents a simulation of central government expenditures under a scenario of gradual adjustment of the minimum wage. In this scenario, wages would rise to USD 75 in the first year, and then gradually increase in USD 75 increments until reaching USD 300 by the fourth year; after that, it rises with expected US inflation. ${ }^{42}$ The USD 300 wage corresponds to a wage that is approximately equal to that of neighboring countries.

The simulations make some additional macroeconomic assumptions, listed on table 9. It is important to point out that a full development of the underlying macroeconomic assumptions of fiscal scenarios is beyond the scope of this paper and that the calculations presented here should be seen as illustrative and certainly not as definitive. For example, we assume that oil production recovers gradually at a speed of $500 \mathrm{tbd}$ per year to reach $3 \mathrm{mbd}$ by 2023 . This speed of recovery would be consistent with that observed in other countries where oil production decline has been caused primarily by sanctions - though, as we pointed out above, the magnitude of the contribution of sanctions to Venezuela's output decline remains controversial. Very different fiscal scenarios may ensue under more pessimistic oil production forecasts.

The underlying fiscal model assumes no major changes in tax legislation, making government revenues dependent on the evolution of the economy, given historical elasticities of different categories of revenue to income growth estimated over the 1998-2016 period. There are some exceptions to this principle: we assume, for example, privatization proceeds equivalent to USD 9bn, or approximately $1 \%$ of GDP each year, over the course of the five year program. It is worth noting that

41. Low real wages are symptomatic of terminal-stage hyperinflations; thus, the end of stabilization tends to produce a sizable increase in real wages. Braumann (2000) shows that the ground lost in real wages during hyperinflation is typically recovered with stabilization.

42. Given the hyperinflationary process, it is more informative to estimate the government budget and revenues in dollar than in local currency terms. These budgets should be understood to refer to post-stabilization period and thus presume stable prices. 
complete fiscal accounts are unavailable for more recent periods (even the data for 2013-2016, as noted above, is limited) so that it is difficult to understand what the country's exact current fiscal stance, and starting point for these simulations, should be. Thus, our revenue projections should be understood as approximations to expected revenue categories given historical experience. On the spending side, we estimate the government payroll as a function of average wages, in themselves determined by minimum wage policy, and add o top of that the magnitude of social spending destined to emergency programs.

TABLE 9

Key assumptions

\begin{tabular}{lccccc}
\hline & $2019-2020$ & $2020-2021$ & $2021-2022$ & $2022-2023$ & $2023-2024$ \\
\hline Oil production (million b/d) & 1,0 & 1,5 & 2,0 & 2,5 & 3,0 \\
Oil price (brent) & 61,5 & 63,3 & 65,2 & 66,9 & 68,7 \\
Minimum wage & 75 & 150 & 225 & 300 & 330 \\
Subsidy per adult & 25 & 25 & 25 & 25 & 25 \\
Subsidy per child & 10 & 10 & 10 & 10 & 10 \\
Subsidy coverage (\% of population) & 75,0 & 80,0 & 65,0 & 50,0 & 35,0 \\
Pension as \% of minimum wage & 65,0 & 65,0 & 65,0 & 65,0 & 65,0 \\
Write-off of restructured debt (\% of face-value) & 75,0 & 75,0 & 75,0 & 75,0 & 75,0 \\
GDP (USD mn) & 77.232 & 123.895 & 172.122 & 221.260 & 272.678 \\
\hline
\end{tabular}

Elaborated by the authors.

We assume that some type of compensatory social policy is rolled out with cash subsidies of USD 25 per eligible adult and USD 10 per eligible child. We assume that these subsidies would be conditioned on incomes, so as wages recover, the coverage ratio would fall. Spending on the program would peak at USD 6.2bn in 2020/2021 and decline towards USD 2.8bn by 2023/2024. We also assume that the government pays pensioners a pension that is equivalent to $65 \%$ of the minimum wage, as well as a debt restructuring that manages to cut amortizations to zero and interest payments to $25 \%$ of the outstanding for the first five years.

The results of these fiscal simulations are sketched in table 10. The program would require Venezuela to run a fiscal deficit of USD 5.2bn, or $6.8 \%$ of GDP, in the first year. The deficit rises in absolute terms but declines relative to GDP as program implementation proceeds; by 2023 the country is running a small surplus $(0.2 \%$ of GDP). The deficit is closed mostly by recovering oil production, which pushes up both oil revenues but also leads GDP in dollars to expand considerably. Thus, by 2023, the economy has recovered to a GDP of USD 273bn, similar to its level at the start of the crisis. 
TABLE 10

Central government fiscal balance simulation (USD mn)

\begin{tabular}{lrrrrr}
\hline & $2019-2020$ & $2020-2021$ & $2021-2022$ & $2022-2023$ & $2023-2024$ \\
\hline Total revenues & 17.508 & 28.081 & 39.098 & $\mathbf{5 0 . 4 9 8}$ & $\mathbf{6 2 . 3 5 0}$ \\
Current revenues & 16.736 & 26.842 & 37.377 & 48.281 & 59.623 \\
Tax revenues & 9.735 & 15.544 & 21.561 & 27.751 & 34.151 \\
$\quad$ Non-tax revenues & 7.001 & 11.298 & 15.816 & 20.530 & 25.472 \\
Capital revenues & 772 & 1.239 & 1.721 & 2.216 & 2.727 \\
Total expenditures & 22.732 & 37.085 & $\mathbf{4 8 . 6 8 9}$ & $\mathbf{5 9 . 3 0 5}$ & $\mathbf{6 1 . 8 8 8}$ \\
Current expenditures & 21.774 & 35.549 & 46.556 & 56.559 & 58.508 \\
Operating expenditures & 11.389 & 21.639 & 30.835 & 39.058 & 40.816 \\
$\quad$ Salaries & 9.159 & 17.403 & 24.799 & 31.412 & 32.826 \\
$\quad$ Goods and services purchases & 1.946 & 3.698 & 5.269 & 6.674 & 6.974 \\
Other & 283 & 539 & 767 & 972 & 1.016 \\
Interest on debt & 1.025 & 1.486 & 1.839 & 2.240 & 2.186 \\
$\quad$ Internal debt & 1 & 1 & 1 & 1 & 1 \\
External debt & 1.024 & 1.485 & 1.838 & 2.239 & 2.185 \\
Transfers & 9.361 & 12.424 & 13.882 & 15.260 & 15.506 \\
Subsidy programs & 5.736 & 6.192 & 5.088 & 3.959 & 2.802 \\
Social security & 1.476 & 3.085 & 4.839 & 6.749 & 7.764 \\
Transfers to SOEs & 905 & 1.151 & 1.181 & 982 & 545 \\
Transfers to subnational governments & 1.245 & 1.997 & 2.774 & 3.572 & 4.394 \\
Capital expenditures & 957 & 1.535 & 2.133 & 2.747 & 3.379 \\
\hline
\end{tabular}

Elaborated by the authors.

The program generates net financing needs of USD 32.6bn over the course of the five-year period. ${ }^{43}$ Under an Extended Fund Facility Arrangement, the maximum that can be requested to the IMF over the course of a program (barring exceptional access) is $435 \%$ of quota, which would equal USD $22.4 \mathrm{bn}$. It is, of course, possible that other international organisms make up the difference, as it is not unusual for the World Bank and Inter-American Development Bank (IADB) to jointly cover around a third of disbursements in loan programs.

However, financing of the central government budget is only one of the country's financing needs. The country would also need to restore convertibility of the currency, for which it would need international reserves. Venezuela currently has USD 8.5bn of international reserves. The IMF has suggested that reserve adequacy should be calculated as a function of exports, broad money,

43. We assume that all debt which comes due over this period can be rolled over, either voluntarily or as a result of the debt restructuring. If it cannot, then we would have to add amortization payments to the financing schedule. 
short-term debt and other liabilities. Table 11 shows the calculation of these ratios for Venezuela under a scenario of economic reforms.

Perhaps surprisingly, current reserves are not too inadequate for the country at the start of a scenario of reforms. This is because the economy is very small, and even though we expect it to grow with reforms, that expansion will take time. Thus adequate reserves are only USD 6-8bn for a floating exchange rate system but would grow over time so as to rise to USD 17-USD 25bn by 2023 . The requirements are much higher if the country is going to maintain a fixed exchange rate, in which case it would rise to USD 9-14bn in the near term and USD 30-USD 45bn by 2023.

TABLE 11

Reserve adequacy estimates (USD bn)

\begin{tabular}{|c|c|c|c|}
\hline Concept & & 2019 & 2023 \\
\hline Exports & & 18,0 & 63,4 \\
\hline Broad money & & 24,5 & 172,9 \\
\hline Short-term debt & & 6,9 & 11,9 \\
\hline Other liabilities & & 9,6 & 9,6 \\
\hline \multirow{2}{*}{ ARA - floating fx range } & Lower bound & 5,6 & 16,8 \\
\hline & Uper bound & 8,4 & 25,2 \\
\hline \multirow{2}{*}{ ARA - fixed fx range } & Lower bound & 9,2 & 30,1 \\
\hline & Uper bound & 13,8 & 45,1 \\
\hline \multirow{2}{*}{ Dollarization } & Base money & 8,2 & 57,6 \\
\hline & Base money + reserves & 12,0 & 71,3 \\
\hline
\end{tabular}

Elaborated by the authors.

Another policy alternative would be to dollarize the economy or adopt an irrevocably fixed exchange rate with a currency board. In that case, the immediate requirements of means of payment for the economy would be what is needed to exchange all base money for USD, which would rise to USD 8.2bn (assuming hyperinflation comes to an end and money demand rises to normal levels). If, in addition, we would like to have the Central Bank continue to perform monetary policy, we estimate an additional USD 3.8bn would be needed. Dollarization is not particularly onerous at the start in terms of monetary requirements. However, over time the economy would require significant growth in its liquidity, making this system the costliest in the long-run in terms of financing needs.

In either case, the economy would need at the very least an additional USD $8 \mathrm{bn}$ - and possibly as much as USD 60bn over the next five years - to have a functional external payments system. Not all of these resources need to be obtained from international financial institutions (IFIs): presumably, capital inflows could 
also be a driver of reserve strengthening. However, recent experiences such as that of Argentina suggest that countries trying to defend an exchange rate objective as part of a stabilization plan could end up demanding significant financing from the IMF in addition to what is needed to close fiscal gaps. Note also that different foreign currency arrangements could differ in their ability to attract private capital inflows. Since dollarization serves as a guarantee that the government will not inflate away cash holdings, it could lead to greater capital inflows or even just the entry into the financial system of dollars that are currently held in safe deposit boxes by individuals. Therefore, dollarization could in the end be easier to fund than other apparently less onerous systems.

If our fiscal estimates presented in the previous section are accurate, it should not be difficult to put an end to hyperinflation, given adequate financing to cover the deficits sketched in table 10. When the government does not need to monetize the deficit at post-stabilization prices, hyperinflation ends as soon as one can get agents to converge to stable price expectations. The reversion of the Olivera-Tanzi effect is near-immediate and typically generates enough revenues to cover spending levels at the start of the program. Expectations are often anchored by fixing the exchange rate or making a firm commitment to price stability. However, this type of programs are always vulnerable to expectations crises, in which authorities have to either sell reserves or raise interest rates in order to fight off speculative attacks. In that sense, a currency board or dollarization may prove to be a more effective strategy for rapidly achieving price stabilization. Since the commitment not to print money is perfectly credible under hyperinflation, authorities do not need to invoke contractionary monetary policy nor reserve depletion in order to tackle problems caused by imperfect credibility.

In choosing an exchange rate regime, authorities will need to carefully balance the short-term effects of alternative systems with the long-run flexibility. A flexible rate system may be the most difficult to manage in a stabilization attempt with imperfect credibility, as the 2018 Argentinean currency crisis recently reminded us of. Irrevocably fixed exchange rates have the benefit of granting credibility to the commitment to monetary stability. This makes it easier to get out of hyperinflation and reduces the risk that the monetary authority will have to appeal to contractionary policies to realign expectations. The social and economic cost of these contractionary policies, as well as the political risk that they may derail the adjustment, are important reasons to consider these systems. On the other hand, the lack of exchange rate flexibility may be particularly constraining for an economy like Venezuela's, which is subject to external shocks that are not strongly correlated with those of the economy whose monetary policy it is adopting. An interesting alternative could be to consider tying to the 
currency of another oil producing economy whose monetary policy is subject to the same shocks (e.g., Canada or Norway). ${ }^{44}$

\subsection{Recovering growth}

Historically, Venezuelan growth has been driven by oil export revenues. The channels are quite straightforward: since the economy is (for all relevant purposes) completely specialized in oil, then oil revenues form almost the totality of export revenues. Since the non-oil economy is highly import-dependent, as we showed in section 2, economic growth is driven by imports (which are, of course, paid for with export revenue). As we also discussed in section 2, economies that are more diversified are much less sensitive to terms of trade shocks than completely specialized economies.

The association between oil exports and GDP does not only hold in the short-term; it is also stable over long periods of time, suggesting a long-term structural relationship. As chart 8 shows, the ratio of GDP measured in United States dollars to exports, also measured in current dollars, oscillates around a stable average of around 4.1; in other words, GDP tends to converge to approximately four times oil exports. While there is substantial, volatility in the ratio - driven by periods of real exchange rate misalignments - the stability of the ratio over the long term suggests that the essential driver of long-run growth in Venezuela is oil export revenue growth.

CHART 8

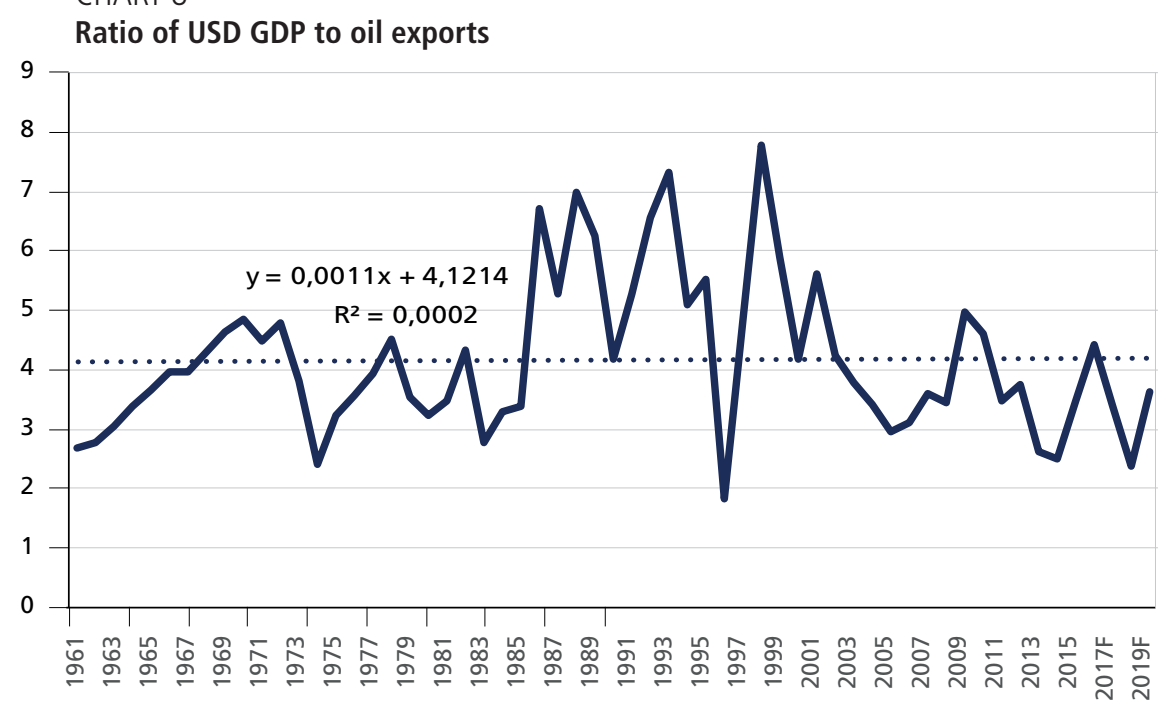

Source: BCV; IMF.

44. Some contributions to the debate on the dollarization option in Venezuela, see Balza (2017), Hausmann (2018) and Rodriguez (2018b). 
This is not necessarily a good thing and is certainly one of the drivers of the country's history of macroeconomic volatility. Yet it would be naïve to think that this structural characteristic can be changed overnight if it has remained unchanged for the past sixty years. The idea that economic policy should focus on changing the economy's structural dependence on oil has been at the center of Venezuelan policy debates ever since Arturo Uslar Pietri, one of the nation's most important intellectuals, proposed it in a 1936 article titled Sowing the oil (Pietri, 1936). Yet despite forming part of the nation's policy consensus for most of the twentieth and twenty-first centuries, the country has been unable to make much headway in resolving this structural dependency.

Nor is it a completely uncontroversial idea. Venezuela is, in fact, an oil-abundant economy, for which conventional gains-from-trade analysis suggests it is optimal to exploit its comparative advantage in oil. ${ }^{45}$ In fact, judged by proven reserve numbers, Venezuela appears to be the most oil abundant country in the world, with 10.4 thousand barrels of oil reserves per capita. Theory tells us that it makes perfect sense for an economy with such characteristics to be highly specialized in oil. In fact, it suggests that Venezuela may not be specialized enough in oil, given that its oil production is lower than that of many countries with fewer reserves.

TABLE 12

Per capita proven reserves

\begin{tabular}{llcc}
\hline Rank & Country & Per capita barrels of proven reserves (bbl) & Total reserves (mn bbl) \\
\hline 1 & Kuwait & 22.191 & 101.500 \\
2 & Venezuela & 10.375 & 302.809 \\
3 & United Arab Emirates & 9.377 & 97.800 \\
4 & Qatar & 9.284 & 25.244 \\
5 & Saudi Arabia & 8.019 & 266.260 \\
6 & Libya & 7.426 & 48.363 \\
7 & Iraq & 3.862 & 147.223 \\
8 & Iran & 1.917 & 155.600 \\
9 & Kazakhstan & 1.625 & 30.000 \\
10 & Oman & 1.261 & 5.373 \\
\hline
\end{tabular}

Source: OPEC; IMF.

Further, diversification is not only or not even the optimal way to deal with fluctuations in revenues. Oil exporting countries can try to hedge their oil exports (by purchasing insurance against price drops) or can deposit a fraction of foreign-currency earnings in a macroeconomic stabilization fund. Such a fund -

45. See the arguments in the contributions to García (2018). 
which is mandated by article 321 of the Venezuelan Constitution - was initially created in 1998, and accumulated as much as USD 7.1bn by late 2001. However, it was later gutted by the government, which reformed the laws to make deposits into the fund completely discretionary. Had the government observed the original accumulation rule, we estimate that it would have accumulated up to USD 203 bn in net savings by $2013 .{ }^{46}$

For these reasons, we would not advocate devoting significant resources to pursuing an objective of diversification at the outset of a program of policy reforms. As a first-order objective of reforms, it would be necessary to direct most available resources to funding the government and reestablishing a payments system while ensuring fiscal stability and to recovering the oil sector so as to reestablish the economy's capacity for growth while providing basic governability and rule of law. This is not to say that sectoral policies should not be developed within that framework, but given limited economic and organizational resources, we would recommend not making this a focus of policy at first stage.

Estimates of the amount of resources needed to recover production in the oil industry are scant. Oil experts have given amounts of USD 15-USD 25bn a year and have estimated a recovery of $1-2 \mathrm{mbd}$ in production over the next 5-7 years. ${ }^{47}$ Levels of investment of USD 15-USD 25bn are similar to what PDVSA was investing up until 2014 and were consistent with a long period of production stability, so it is natural to expect that if such investment rates were attained, then production would converge to levels similar to those of the 2008-2015 period.

That said, there are some interesting facts that come out of the data. One is that, while investment averaged USD $18.3 \mathrm{bn}$ in the $2008-2015$ period, a big part of that went to non-oil subsidiaries, including firms in agriculture and food supply, electric plants and construction in addition to "corporate contingencies" and expenses not-specified (Hernández and Monaldi, 2016). If we exclude these, investment falls to an average of USD $14.2 \mathrm{bn}$ over this period. The other fact is that investment in the 1999-2006 period was much lower (USD 3.8bn, excluding non-oil subsidiaries). Although oil production did decline in this period (from 2.8 to $2.5 \mathrm{mbd}$ ), the decline appears to be most associated with the government takeover and strike in PDVSA in 2002-2003.

In any case, it would appear that there are good reasons to expect that the economy would require investments of around USD 15bn per year for the next

46. The fund's holdings in the original law were capped at $80 \%$ of oil revenues, which would have been USD 62.0bn in 2013. However, the excess deposits in the funds would be transferred back to the regions, PDVSA and the Republic, with the Republic obligated to use its resources to lower debt. The cumulative sum of those excess funds returned to the government would have been USD 141.3bn by the end of 2017.

47. The lower ends of these ranges (150tbd recovery per year, USD 15bn investment) were given by personal communication with Francisco Monaldi of Rice University. For the higher end of the range, see Descifrado (2018). 
five years for the oil industry. It would also appear that, at least at the outset of the program, it would not be viable for PDVSA to fund this out of its own revenues (certainly not out of the USD 16bn of imports that we would expect in the first year of implementation). If we take the historical share of oil investment to exports as a rough proxy for PDVSA's capacity to fund investments from its own revenues, we estimate that PDVSA would be able to devote a total of USD 30bn to oil investments over a five-year period (USD 6bn per year). This implies that private financing would have to fund about USD $41 \mathrm{bn}$ of investment (starting out from an USD 14.2bn annual figure, or USD 71.0bn over five years).

CHART 9

Oil industry investments (1999-2015)

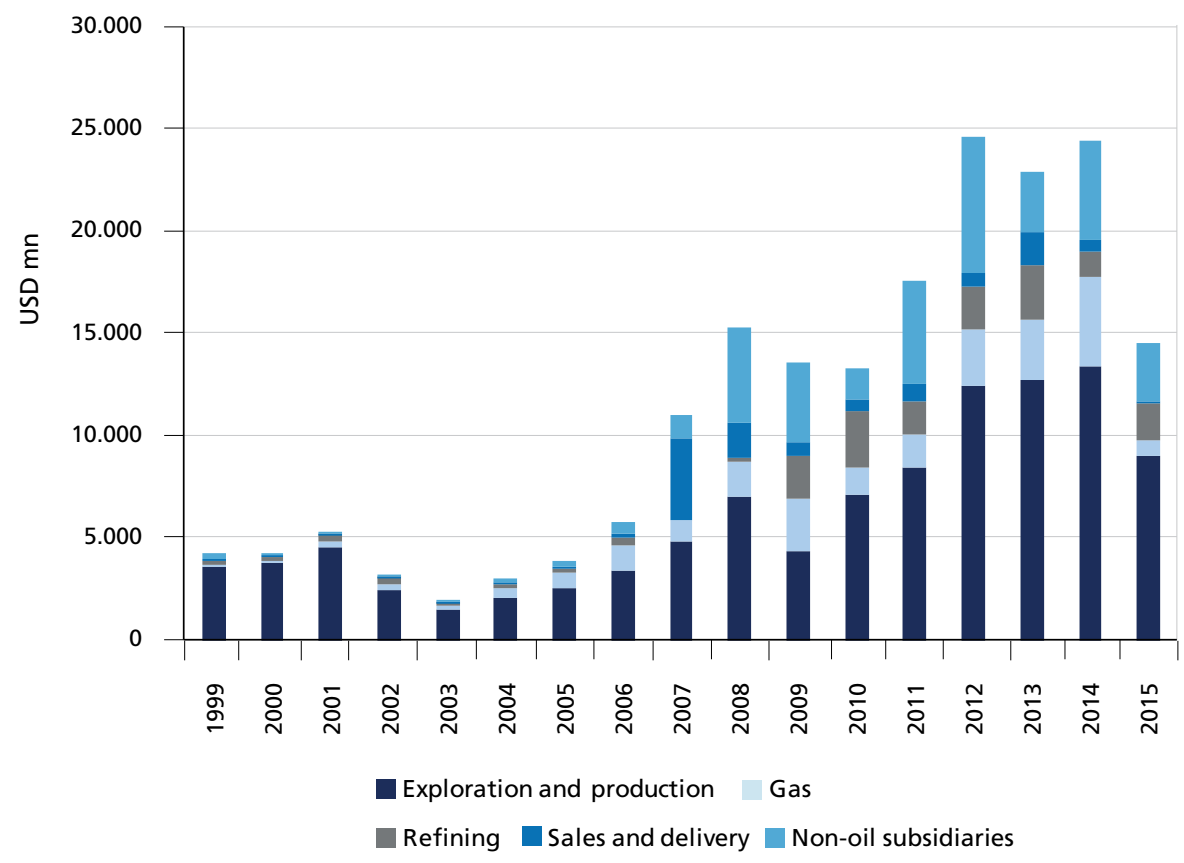

Source: PDVSA.

In principle, financing from IFIs would not be available to fund the country's oil sector. IFIs lend to national and sub-national governments, but typically not to state-owned corporations that are not directly involved in providing public services (e.g., public utilities). If Venezuela's oil barrels are profitable to extract, then private financing (either lending or equity) should be available to develop them in global financial markets. The policy focus should be in producing the institutional reforms that ensure the protection of property rights and conditions for private investment in the oil sector. 
This brings us to the issue of external debt. Venezuela's external public sector debt is currently at USD $165.2 \mathrm{bn}$. This represents $278 \%$ of 2020 GDP, making it the world's most indebted nation. Debt service accounted for $188 \%$ of exports in $2019,{ }^{48}$ also the highest among developing countries by this metric. The country has been in default on most of its external debt obligations since the end of 2017. Currently, the country is shut out of capital markets due to financial sanctions, but any attempt to re-enter capital markets would require resolving the default, and this would require a very complex debt restructuring.

TABLE 13

Debt service as a \% of exports (2019)

\begin{tabular}{|c|c|c|c|c|c|}
\hline Country & $\begin{array}{l}\text { Debt service total } \\
\text { as } \% \text { of exports }\end{array}$ & Country & $\begin{array}{l}\text { Debt service total } \\
\text { as } \% \text { of exports }\end{array}$ & Country & $\begin{array}{l}\text { Debt service total } \\
\text { as } \% \text { of exports }\end{array}$ \\
\hline Venezuela, RB & 188,16 & Ukraine & 23,14 & Mozambique & 13,70 \\
\hline Mongolia & 95,87 & Russian Federation & 22,81 & Peru & 12,62 \\
\hline Montenegro & 71,37 & Albania & 22,56 & Azerbaijan & 12,09 \\
\hline Kazakhstan & 51,23 & South Africa & 22,30 & Mexico & 11,88 \\
\hline Colombia & 46,72 & Serbia & 21,89 & Bosnia and Herzegovina & 11,73 \\
\hline El Salvador & 44,53 & Romania & 21,37 & India & 11,66 \\
\hline Brazil & 36,72 & Pakistan & 20,04 & Ghana & 11,66 \\
\hline Sri Lanka & 36,49 & Costa Rica & 18,36 & Uganda & 11,30 \\
\hline Ecuador & 35,02 & Zambia & 17,75 & Bolivia & 9,81 \\
\hline Turkey & 34,05 & Paraguay & 17,25 & Philippines & 9,29 \\
\hline Armenia & 31,84 & Bulgaria & 15,51 & China & 8,91 \\
\hline Kyrgyz Republic & 30,21 & Dominican Republic & 15,17 & Morocco & 8,78 \\
\hline Guatemala & 29,15 & Jordan & 15,04 & Nigeria & 8,54 \\
\hline Honduras & 28,46 & Arab Republic of Egypt & 14,73 & Vietnam & 7,13 \\
\hline Indonesia & 28,33 & Tunisia & 14,36 & Bangladesh & 6,21 \\
\hline Georgia & 25,25 & Belarus & 13,81 & Thailand & 5,70 \\
\hline
\end{tabular}

Source: Haver; World Bank.

A detailed examination of the potential avenues for restructuring the nation's debt is outside the scope of this work. However, one important fact that is worth highlighting in a general discussion is that there is one dimension in which debt stocks do not seem high. If we measure the ratio of PDVSA debt to its oil reserves, we find one of the lowest ratios among major oil companies (table 14). This is despite the fact that PDVSA has an external debt stock of USD $63 \mathrm{bn}$, or $44 \%$ of the country's external debt.

48. We include Past Due Interest in our estimation of Venezuela's debt service. Referential data for other countries is as of 2018. 
TABLE 14

Ratio of financial debt to proven oil reserves for mayor oil companies

\begin{tabular}{lclc}
\hline Oil company & Debt/reserves (USD/boe) & Oil company & Debt/reserves (USD/boe) \\
\hline Enap & 31,31 & Petronas & 3,11 \\
Suncor Energy & 28,83 & Canadian Natural Resources & 2,87 \\
Ecopetrol & 11,20 & Chevron & 2,32 \\
Statoil & 8,75 & Total SA & 1,72 \\
YPF & 8,43 & Rosneft & 1,64 \\
Pemex & 7,49 & ConocoPhillips & 1,33 \\
Petrobras & 6,18 & Royal Dutch Shell & 1,29 \\
Sinopec & 4,99 & Saudi Aramco & 0,12 \\
Average & 4,98 & PDVSA & 0,13 \\
Eni S.p.A & 3,68 & Gazprom & 0,09 \\
Repsol & 3,64 & BP & 0,03 \\
Exxon Mobil & 3,19 & Petroecuador & 0,01 \\
\hline
\end{tabular}

Source: Bloomberg; companies' financial statements; online resources.

These observations suggest that it may be wise to separate the PDVSA debt problem from that of the sovereign. PDVSA appears to have a greater capacity to repay debt if it can successfully implement an investment strategy that allows it to increase oil production. But PDVSA also has a much greater cost of default, given that its revenue flows and assets are not protected by the principle of sovereign immunity, pertaining as they do to a commercial activity. This it appears that PDVSA may have greater reasons to reach an amicable resolution to its debt problems. In the case of the sovereign, in contrast, the greater protection offered by sovereign immunity, collective action clauses, and the corporate veil separating an entity from its owner would give more bargaining power for the government to reach a more favorable restructuring.

\subsection{Fixing social policies}

As discussed in section 2, there are three pillars to Venezuela's current social policy framework. One is the traditional structure of social ministries which in charge of the nation's health and education infrastructure. Another one is a set of ad hoc social programs created over the last two decades - called misiones (missions) aimed at solving specific problems such as illiteracy or housing. The third one is a set of direct subsidy programs created in recent years, including in-kind and monetary transfers such as food boxes and a benefits card.

Since misiones are created at the time at which the problem they deal with are a policy focus, they often end up underfunded and falling out of the radar screen over time. They also duplicate efforts that could well be managed from 
inside ministries. Fixing this by integrating them into the state structure would nevertheless require a significant restructuring of the state and assurance that the ministries in charge have the capacity to handle the areas covered by the ad hoc programs.

Venezuela has traditionally relied on large indirect subsidies - implemented through price and exchange controls - in order to transfer oil rents to its residents. Despite its negative aspects, the new direct transfer programs set up the necessary infrastructure for replacing the indirect subsidies.

In its current incarnation as the Card of the Fatherland, the benefits card is in principle a universal program in that no Venezuelans above the age of 15 are denied access to it. Some of the cash bonuses paid through the card are targeted only at some recipients (e.g., pregnant mothers). Nevertheless, the program is not in general means-tested, nor is it conditional on recipient actions. It would not be difficult, within the framework of the program, to design in such a way so that it could be compatible with means-testing and conditionality on actions or outcomes. The program would of course have to be re-designed and launched ideally under a new label - to eliminate any type of political conditioning.

The food boxes program could serve an important transitional purpose while the country's private distribution network is being rebuilt and restocked. In the longer term, it could be phased down in order to focus on areas in which the private sector distribution network is insufficient. However, the benefits card would be a more efficient system to allocate in-kind transfer, in the form of cash credits that can only be used for the purchase of certain goods.

\subsection{Strengthening the institutional framework}

Venezuela's public sector has become involved in just about all kinds of economic activity, from food production to airlines. It has also built up a massive regulatory apparatus, including for the purposes of enforcing price controls. Meanwhile, declining public sector wages have led to an exodus of skilled workers out of the public sector and out of the country. Therefore, one of the main tasks of a new administration would be that of rebuilding institutional capacity to focus on key state functions.

A broader set of institutional reforms are also necessary to allow Venezuela to become a stable democracy. Much of the country's political polarization can be traced back to institutional reforms in the late 90 s which sought to concentrate power in the hands of the elected executive. These reforms - particularly those embodied in changes in electoral laws through the nineties and in the 1999 Constitution - created a toxic mix of centralized power, high stakes of the 
political contest, and very frequent elections ${ }^{49}$ Governments faced with high cost of losing power who are also forced to face very frequent elections will have a bias towards short-term policies and to abuse the power of state institutions in order to attempt to remain in power.

Therefore, a set of institutional reforms are necessary to ensure governability by restoring effective separation of powers, reducing the authority of the executive branch over other branches of government, and appropriately protecting the rights of political minorities. This would require reforms to the electoral system as well as to the framework governing the relationship between different branches of government, and quite possibly a constitutional reform.

A key area is human rights. In a recent report, the UN High Commissioner on Human Rights, Michelle Bachelet, outlined grave human rights violations observed by her office in the country, including torture, extrajudicial executions, and persecution of political opponents. It also noted serious shortcomings in the government actions to ensure access to food and health services. The government claims that Office of the United Nations High Commissioner for Human Rights (UNOHCHR) ignored data and evidence presented to it by authorities. The report outlines 23 special recommendations, including the disbanding of special police forces (FAES) behind the killings and the freeing of all political prisoners (Human Rights Council, 2019).

\section{CONCLUDING COMMENTS}

A strategy for putting Venezuela on the road toward sustainable human development requires halting and reverting the deepest economic collapse in Latin American economic history. Although many factors have contributed to the country's economic implosion, the proximate factor causing the bulk of the country's decline has been a massive reduction in imports generated by dwindling foreign exchange revenue. Any strategy for recovering growth must thus start from a plan to recover the economy's capacity to generate foreign exchange through the recovery of its export sector and the reopening of access to international financing.

Venezuela's economy has been strongly dependent on oil for the last one hundred years. Oil accounts for more than nine-tenths of the economy's exports even after the collapse in oil revenues. Whether this is desirable given the country's strong comparative advantage in oil is debatable; however, given the urgency of addressing the country's lack of import capacity and other basic reforms, we would not advocate trying to change this structural characteristic of the economy at present. Rather, we suggest concentrating in recovering oil production and

49. See Rodriguez (s.d.), chapter 6. 
reestablishing access to international financing as the pillars of a rapid strategy of economic recovery, dealing with export diversification as an objective that should be addressed in a second generation of reforms.

Ultimately, what the country can do - and what the international community can help it to do - will depend on the evolution of its politics and politically-driven external constraints. Under a continuation of the current status $q u o$, in which the country's government is not recognized by most nations in the hemisphere and Europe and is subject to financial and economic sanctions, the range of policy options is limited and the international community's assistance should focus on helping minimize the harm that this crisis will produce among most vulnerable Venezuelans. If these political restrictions are lifted, the range of policy options and the scope for policy assistance will be much broader. However, it is possibly in the former scenario where international assistance will be most urgently needed, and where the promptness of the international response will make a greater difference to Venezuelan lives.

\section{REFERENCES}

AHN, M. J.; CHOI, M. J. From firm-level imports to aggregate productivity: evidence from Korean manufacturing firms data. [s.l.]: International Monetary Fund, 2016. (Working Paper, n. 16/162).

ARAUJO, J. A.; FEITOSA, D. G.; SILVA, A. B. D. América Latina: productividad total de los factores y su descomposición. Revista Cepal, n. 114, 2014.

BAHAR, D. et al. Impact of the 2017 sanctions on Venezuela: revisiting the evidence. [s.l.]: Brookings Institution, 2019. Available at: <https://www.brookings. edu/research/revisiting-the-evidence-impact-of-the-2017-sanctions-on-venezuela/>.

BALZA, R. La dolarización de Hanke y el bálsamo de Fierabrás. Prodavinci, 2017. Available at: <https://prodavinci.com/la-dolarizacion-de-hanke-y-elbalsamo-de-fierabras/>.

BBC - BRITISH BROADCASTING CORPORATION. Venezuela: Maduro decreta el estado de excepción en una parte de la frontera con Colombia. [s.l.]: BBC, 2015. Available at: <https://www.bbc.com/mundo/noticias/2015/08/150821_ venezuela_estado_excepcion_colombia_ep $>$.

BRAUMANN, M. B. Real effects of high inflation. [s.l.]: International Monetary Fund, 2000.

CAGAN, P. The monetary dynamics of hyperinflation. In: FRIEDMAN, M. (Ed.). Studies in the quantity theory of money. Chicago: Chicago University Press, 1956. p. 25-117. 
CHANG, R.; HEVIA, C.; LOAYZA, N. Privatization and nationalization cycles. Macroeconomic Dynamics, v. 22, n. 2, p. 331-361, 2018.

CLAUSEN, M. J. R. et al. Lessons from high inflation episodes for stabilizing the economy in Zimbabwe. [s.l.]: International Monetary Fund, 2007. (Working Paper, n. 7/99).

COHEN, L. U. S. court grants stay in PDVSA debt cases due to Venezuela 'political situation'. Reuters, 2019. Available at: <https://www.reuters.com/ article/us-venezuela-politics-debt/u-s-court-grants-stay-in-pdvsa-debt-cases-dueto-venezuela-political-situation-idUSKCN1SC29T>.

DESCIFRADO. PDVSA debe invertir \$ 25 mil millones al año para recuperar producción dijo Toro Hardy. Descifrado, 2018. Available at: <http://www. descifrado.com/2018/12/07/pdvsa-debe-invertir-25-mil-millones-al-ano-pararecuperar-produccion-dijo-toro-hardy/>.

FINCEN - FINANCIAL CRIMES ENFORCEMENT NETWORK. FinCEN Warns Financial Institutions to Guard Against Corrupt Venezuelan Money Flowing to U.S. Sep. 20, 2017. Available at: <https://www.fincen.gov/news/ news-releases/fincen-warns-financial-institutions-guard-against-corruptvenezuelan-money>.

GARCÍA, H. La ilusión de la 'Siembra del Petróleo'. Caracas: Cendes, 2018.

HALPERN, L.; KOREN, M.; SZEIDL, A. Imported inputs and productivity. American Economic Review, v. 105, n. 12, p. 3660-3703, 2015.

HANKE, S.; KRUS, N. World hyperinflations. Washington: Cato Institute, 2012. Available at: <https://papers.ssrn.com/sol3/papers.cfm?abstract_id=2226980>.

HAUSMANN, R. El espejismo de la dolarización. Prodavinci, 2018. Available at: <https://prodavinci.com/el-espejismo-de-la-dolarizacion/>.

HAUSMANN, R.; HINZ, J.; YILDIRIM, M. A. MeasuringVenezuelan emigration with twitter. [s.l.]: Kiel, 2018. (Working Paper, n. 2106). Available at: <https:// growthlab.cid.harvard.edu/files/growthlab/files/ven_emigration_cidwp342.pdfs.

HAUSMANN, R.; MUCI, F. Don't blame Washington for Venezuela's oil woes: a rebuttal. Americas Quarterly, 2019. Available at: <https://www.americasquarterly. org/article/dont-blame-washington-for-venezuelas-oil-woes-a-rebuttal/>.

HAUSMANN, R.; RIGOBON, R. An alternative interpretation of the 'resource curse': theory and policy implications. [s.l.]: National Bureau of Economic Research, 2003. Available at: <https://www.nber.org/papers/w9424>. 
HAUSMANN, R.; RODRÍGUEZ, F. Why did Venezuelan growth collapse? In: HAUSMANN, R.; RODRÍGUEZ, F. (Ed.). Venezuela before Chávez: anatomy of an economic collapse. University Park: Penn State University Press, 2011.

HAUSMANN, R.; SANTOS, M. A. ShouldVenezuela default? Cambridge: Project syndicate, 2014. Available at: <https://www.project-syndicate.org/commentary/ ricardo-hausmann-and-miguel-angel-santos-pillory-the-maduro-government-fordefaulting-on-30-million-citizens-but-not-on-wall-street?barrier=accesspaylog>.

HERNÁNDEZ, I.; MONALDI, F. Weathering collapse: an assessment of the financial and operational situation of the Venezuelan oil industry. Cambridge: Growth Lab, 2016. Available at: <https://growthlab.cid.harvard.edu/publications/ venezuelan-oil-assessment>.

HOFFMANN, A. Standardised capital stock estimates in Latin America: a 1950-94 update. Cambridge Journal of Economics, v. 24, n. 1, p. 45-86, 2000.

HULTEN, C. R. Growth accounting with intermediate inputs. The Review of Economic Studies, v. 45, n. 3, p. 511-518, 1978.

HUMAN RIGHTS COUNCIL. Office of the High Commissioner for Human Rights. Report of the United Nations High Commissioner for Human Rights on the situation of human rights in the Bolivarian Republic of Venezuela. New York: United Nations, 2019. Available at: <https://reliefweb.int/report/ venezuela-bolivarian-republic/report-united-nations-high-commissionerhuman-rights-situation>.

HUMAN RIGHT WATCH. Venezuela: numbers highlight health crisis. Washington: Human Right Watch, 2018. Available at: <https://www.hrw.org/ news/2018/11/15/venezuela-numbers-highlight-health-crisis $>$.

KASAHARA, H. RODRIGUE, J. Does the use of imported intermediates increase productivity? Plant-level evidence. Journal of Development Economics, v. 87, n. 1, p. 106-118, 2008.

MORALES, J. R. Sanciones: ¿causa o consecuencia de la crisis? Prodavinci, 2019. Available at: <https://prodavinci.com/sanciones-causa-o-consecuencia-de-la-crisis/>.

OCAMPO, J. A. Collapse and (incomplete) stabilization of the Nicaraguan economy. In: DORNBUSCH, R.; EDWARDS, S. The macroeconomics of populism in Latin America. Chicago: University of Chicago Press, 1991. p. 331-368. Available at: <https://core.ac.uk/download/pdf/6483618.pdf>.

ORTEGA, D.; RODRÍGUEZ, F. Freed from illiteracy? A closer look at Venezuela's Robinson literacy campaign. Economic Development and Cultural Change, v. 57, n. 1, p. 1-30, 2008. 
PATRIA BLOG. Actualización del monto de los planes sociales y económicos de protección. [s.l.]: Patria Blog, 2019. Available at: <https://blog.patria.org.ve/ actualizacion-del-monto-de-los-planes-sociales-y-economicos-de-proteccion/>.

PENFOLD-BECERRA, M. Clientelism and social funds: evidence from Chávez's misiones. Latin American Politics and Society, v. 49, n. 4, p. 63-84, 2007.

PERNIA, A. Falcón impugna elecciones del 20M en el TSJ y exige repetición del proceso. Tal Cual: Claro y Raspao, 2018. Available at: <https://talcualdigital.com/ index.php/2018/05/30/henri-falcon-impugna-elecciones-del-20m-en-el-tsj/>.

PIETRI, A. U. Sembrar el petróleo. Ahora, 1936. Available at: <http://webdelprofesor. ula.ve/economia/ajhurtado/lecturasobligatorias/sembrar\%20el\%20petroleo.pdfs.

PRODAVINCI. Éstas son las nuevas atribuciones de los CLAP, según el Decreto de Estado de Excepción. Prodavinci, 2016. Available at: <http://historico. prodavinci.com/2016/05/17/actualidad/estas-son-las-nuevas-atribuciones-delos-clap-segun-el-decreto-de-estado-de-excepcion/>.

REINHART, C.; SAVASTANO, M. The realities of modern hyperinflation. Finance and Development, v. 40, n. 2, 2003. Available at: <https://www.researchgate.net/ publication/24115535_The_Realities_of_Modern_Hyperinflation>.

REPÚBLICA BOLIVARIANA DE VENEZUELA. Ley Orgánica de Precios Justos (Gaceta Oficial no 40.340, 23 de enero de 2014). [s.l.]: [s.n.], 2014. Available at: <http://www.ucv.ve/fileadmin/user_upload/cendes/Ley-Org\%C3\%A1 nicade-Precios-Justos.pdf $>$.

RODRÍGUEZ, F. An empty revolution: the unfulfilled promises of Hugo Chavez. Foreign Affairs, v. 87, n. 49, 2008a. Available at: <https://www.foreignaffairs. com/articles/venezuela/2008-03-02/empty-revolution>.

. How not to defend the revolution: Mark Weisbrot and the misinterpretation of Venezuelan evidence. Middletown: Wesleyan University, 2008b. Available at: $<$ https://www.researchgate.net/publication/23725275_How_Not_to_Defend_the_ Revolution_Mark_Weisbrot_and_the_Misinterpretation_of_Venezuelan_Evidence>.

. Why Venezuela should not default. Financial Times, 2014. Available at: <https://www.ft.com/content/6e350887-8b55-3150-9eb2-b17ae10fa6b0>.

. Cuando son los colombianos los que llegan de Venezuela. El Espectador, 2018a. Available at: <https://www.elespectador.com/noticias/el-mundo/los-queluchan-contra-el-rechazo-a-los-venezolanos-en-colombia/> .

. La propuesta de dolarización en Venezuela: una guía para los escépticos. Prodavinci, 2018b. 
Sanctions and the Venezuelan economy: what the data say. [s.l.]: Torino Economics, 2019a. Available at: <https://torinocap.com/wp-content/ uploads/2019/06/Sanctions-and-Vzlan-Economy-June-2019.pdf>.

. ¿Cuál ha sido el impacto de las sanciones de EEUU sobre la economía venezolana?, AlNavio.com, June 2019b. Available at: <https://alnavio.es/ noticia/19129/economia/cual-ha-sido-el-impacto-de-las-sanciones-de-eeuusobre-la-economia-venezolana.html>.

. Things fall apart: Nicolás Maduro and the unraveling of Venezuela’s populist experiment. [s.l.]: [s.n.], [s.d.].

RODRÍGUEZ, F.; NAVARRO, P. ¿Cómo moviliza votos el chavismo? Prodavinci, 2018. Available at: <https://prodavinci.com/como-moviliza-votos-el-chavismo/>.

RODRÍGUEZ, F.; SACHS, J. D. Why do resource abundant economies grow more slowly? Journal of Economic Growth, v. 4, n. 3, p. 277-303, 1999.

ROMERO-CASTILLO. Deutsche Bank pone en riesgo su reputación. Deutsche Welle, 2017. Available at: <https://www.dw.com/es/deutsche-bank-pone-enriesgo-su-reputaci\%C3\%B3n/a-38541387>.

SABOIN, J. The modern hyperinflation cycle: some new empirical regularities. [s.l.]: International Monetary Fund, 2018. (Working Paper, n. 266).

SACHS, J. D. The Bolivia hyperinflation and stabilization. AEA Papers and Proceedings, v. 77, n. 2 (May 1987). 2001. (Previously NBER Working Paper, n. 2073, November 1986).

SANTOS, M. A. ¿Cuántos son y qué perfil tienen los venezolanos en el exilio? Una aproximación a través de Facebook. Prodavinci, 2018. Available at: <https:// prodavinci.com/cuantos-son-y-que-perfil-tienen-los-venezolanos-en-el-exiliouna-aproximacion-a-traves-de-facebook/>.

SARGENT, T. The ends of four big inflations. In: HALL, R. E. (Ed.). Inflation: causes and effects, p. 41-98, 1981. Disponível em: <https://www.nber.org/ system/files/chapters/c11452/c11452.pdf>.

SLEINAN, J. P. Casi 40\% de los médicos graduados en los últimos 10 años decidió emigrar, según encuesta. Efecto Cocuyo, 2017. Available at: <https:// efectococuyo.com/salud/casi-40-de-los-medicos-graduados-en-los-ultimos-10anos-decidio-emigrar-segun-encuesta/>.

SPETALNICK M.; ELLSWORTH, B. U. S. sanctions Venezuela state oil firm, escalating pressure on Maduro. Reuters, 2019. Available at: <https:/www.reuters. $\mathrm{com} /$ article/us-venezuela-politics-usa-sanctions/u-s-sanctions-venezuelan-stateoil-firm-escalating-pressure-on-maduro-idUSKCN1PM2DP>. 
TANZI, V. Inflation, lags in collection, and the real value of tax revenue. [s.l.]: International Monetary Fund, 1977. p. 154-167.

UNITED NATIONS. International migrant stock: the 2017 revision. [s.l.]: United Nations, 2017. Available at: <https:/www.un.org/en/development/desa/ population/migration/data/estimates2/estimates17.asp>.

WEISBROT, M.; SACHS, J. Economic sanctions as collective punishment: the case of Venezuela. Washington: Center For Economic and Policy Research, 2019a. Available at: <https://cepr.net/images/stories/reports/venezuelasanctions-2019-04.pdf>.

. Economists use 'fuzzy graphs' to challenge data on the human cost of Trump sanctions on Venezuela. Washington: Center For Economic and Policy Research, 2019b. Available at: <https://cepr.net/economists-use-fuzzy-graphs-tochallenge-data-on-the-human-cost-of-trump-sanctions-on-venezuela/>.

WHO - WORLD HEALTH ORGANIZATION; PAHO - PAN AMERICAN HEALTH ORGANIZATION. Epidemiological update: measles. Washington: PAHO; WHO, 2018a. Available at: <https://www. paho.org/hq/index.php?option=com_docman\&view=download\&category_ slug $=$ measles $-2204 \&$ alias $=46335-21$-september-2018-measles-epidemiologicalupdate\&Itemid $=270 \&$ lang $=$ en $>$.

. Epidemiological update: diphtheria. Washington: PAHO; WHO, 2018b. Available at: <https://www.paho.org/hq/index.php?option=com_ docman \&view=download\&category_slug=diphtheria-8968\&alias=46345-21 september-2018-diphtheria-epidemiological-update- $1 \&$ Itemid=270\&lang=en $>$.

\section{COMPLEMENTARY BIBLIOGRAPHY}

BUCHHEIT, L. C.; GULATI, G. M. How to restructure Venezuelan debt? Durham: [s.n.], 2017. Available at: <https://ssrn.com/abstract=3006680>.

HOFMAN, A. A. Standardized capital stock estimates in Latin America: a 1950-94 update. Cambridge Journal of Economics, v. 24, n. 1, p. 45-86, 2000.

MORALES, J. A.; SACHS, J. D. Bolivia's economic crisis. In: SACHS, J. D. (Ed.). Developing country debt and the world economy. Chicago: University of Chicago Press, 1989. Available at: <https://www.nber.org/books/sach89-3>.

RODRÍGUEZ, F. Don't let Venezuela become the next Libya. Financial Times, 2017. Available at: <https://www.ft.com/content/33abcdaa-461f-11e7-85199f94ee97d996>. 
. Ecuador and Venezuela: this Week. [s.l.]: Torino Economics, 2018. Available at: <https://www.torinocap.com/media/Ecuador\%20\%26\%20Venezuela\%20 this\%20Week\%20-\%20January\%2028,\%202019.pdfs.

VOLCKER, P. A., GOLDSTONE, R.; PIETH, M. Manipulation of the Oil-for-Food Programme by the Iraqi Regime. [s.l]: Independent Inquiry Committee into the United Nations Oil-for Food Programme, 2005. Available at: <https://www.files.ethz.ch/isn/13894/ManipulationReport.pdf>. 
